\title{
UTAJOVANÉ PATENTY
}

\author{
TEREZA NOVOTNÁ
}

\begin{abstract}
ABSTRAKT
Tento článek zpracovává problematiku utajovaných patentů, což jsou patenty obsahující utajované informace. Tento institut tedy leží na pomezí práva ochrany průmyslového vlastnictví a práva ochrany utajovaných informací. Jako takový v sobě obsahuje typické znaky z obou právních odvětví, některé z nich jsou si navzájem $v$ kontradikci. Proto je nejprve diskutována samotná existence tohoto institutu, který je ze své podstaty neveřejným, s ohledem na princip veřejnosti, který je typický pro právo průmyslového vlastnictví.

Následně analyzuje právní úpravu samotného institutu na mezinárodní, evropské a zejména národní úrovni s dưrazem na přesný popis ř́zení o jeho udělení a se snahou definovat $i$ dopad utajování patentu na vlastnická práva $k$ němu. Prostor je věnován zejména tomu, kdo a jak navrhuje stupeň utajení patentové přihlášky, kdo o stupni rozhoduje a jak toto rozhodnutí dále ovlivňuje následné patentové ř́zení. Definována jsou také postavení Úřadu průmyslového vlastnictví, Národního bezpečnostního úřadu a případně dalších ústredních správních orgánů $v$ tomto specifickém ř́zení. Zahrnuta je také část zabývající se rozborem vlivu utajení patentu na vlastnická práva majitele. Tato část je specifická vzhledem $k$ ostatnímu textu zejména absencí relevantních normativních i odborných zdrojů a je proto zpracována mimo jiné i za pomoci odborných konzultací a historického textu.
\end{abstract}

Na závěr je analýza doplněna krátkou komparací s právní úpravou utajovaného patentu v dalších státech, kterými jsou Spojené státy, Spojené království a Německo, která se zaměřuje zejména na rozdílné prvky v ř́zení a případně po-

1 Mgr. Tereza Novotná je studentkou prezenčního doktorského studia na Ústavu práva a technologií Právnické fakulty MU. Kontaktní e-mail: tereza.novotna@mail.muni.cz. 
rovnání některých statistických údajů o počtu utajovaných patentů či patentových přihlášek. Tyto údaje však nebylo možno získat ze všech států. Komparaci následuje úvaha de lege ferenda, ve které je zhodnocena aktuální právní úprava zejména na základě přechozí komparace a navržen směr možné budoucí změny úpravy uajovaného patentu.

\section{KLÍČOVÁ SLOVA}

Utajovaný patent, Patentové právo, Princip veřejnosti, Utajovaná informace, Zájmy České republiky, Omezení vlastnických práv

\section{ABSTRACT}

This article comprehensively deals with the issue of secret patents, which are patents containing classified information. This institute therefore lies within the scope of industrial property rights and the protection of classified information. As such, it contains typical features of both legal branches, some of which are in contradiction. Therefore, the very existence of this institute, which is by its very nature non-public, is discussed with regard to the principle of disclosure, which is typical for the industrial property rights.

It then analyzes the legal regulations of the institute itself at the international, European and, especially, national level, with an emphasis on the precise description of the procedure for its granting and with the effort to define the impact of the patent secrecy on property rights thereon. In particular, this part is devoted to who and how the degree of secrecy of the patent application is proposed, who decides on the degree and how this decision further affects subsequent patent proceedings. The position of the Industrial Property Office, the National Security Authority and possibly other central administrative bodies in this specific management are also defined. A section dealing with the analysis of the effect of patent confidentiality on the owner's property rights $i$ salso included. This part is specific to the other text in particular by the absence of relevant normative and professional resources and is therefore compiled, inter alia, with the help of consultations with experts and historical text.

Finally, the analysis is complemented with short comparison with legal regulations of secret patents in other countries, namely the United States, the 
United Kingdom and Germany, where the focus is mainly on different elements in procedure and this part includes some statistics comparing the number of classified patents or patent applications. However, these data could not be obtained from all countries. The comparison is followed by de lege ferenda evaluation, which evaluates current legislation, in particular on the basis of previous comparisons, and suggests the direction of possible future changes of this legal regulation.

\section{KEYWORDS}

Secret patent, Patent law, Principle of disclosure, Classified information, Interests of Czech republic, Restriction on property rights

\section{UTAJOVANÝ PATENT}

První část tohoto příspěvku má za cíl popsat a analyzovat institut utajovaného patentu, což je problematika, která v českém právním řádu ani na odborné úrovni komplexně popsána není. ${ }^{2}$ Analýza zkoumaného institutu pak bude probíhat od teoretických otázek jeho existence přes řízení až po pravděpodobné dopady udělení utajovaného patentu na soukromý vynález. Vzhledem k absenci relevantních konkrétních zdrojů pak budou některé otázky řešeny pouze na základě obecných principi̊, dopadajících na tento institut, a konzultací s odborníky.

\subsection{UTAJOVANÝ PATENT V KONTEXTU PRINCIPU VEŘEJNOSTI}

Otázka jak anebo dokonce zda-li vůbec chránit výsledky tvůrčí činnosti (a to jak na poli průmyslových vynálezů tak autorských děl) není otázkou novou, nicméně po dobu existence právní ochrany duševního vlastnictví stále stejně kontroverzní. Hlasy ostře se vymezující proti ochraně výsledků vynálezecké činnosti pozorujeme již od poloviny 19. století. ${ }^{3}$

\footnotetext{
2 V tuto chvíli je nutno zmínit, že komentáře $\mathrm{k}$ patentovému zákonu a odborná literatura toto téma nepokrývají.

3 MACHLUP, Fritz; PENROSE, Edith. The Patent Controversy in the Nineteenth Century. The Journal of Economic History [online]. 1950, vol. 10, no. 1, s. 1 - 29 [cit. 6. 1. 2018].
} 
Důležitým argumentem, který vyvažuje vytvoření monopolní ochrany vynálezu, je argument zveřejnění výsledků tvůrčí práce veřejnosti a tím povzbuzení dalšího výzkumu a vývoje. I přes různé názorové proudy, často i podpořené výzkumy a fakty, je argument zveřejním odbornou veřejností brán obecně jako dostačující satisfakce za poskytnutí výlučné ochrany. ${ }^{4}$

Utajované patenty ve zkratce ze své podstaty tuto satisfakci neposkytují. Popis fungování utajovaného patentu je zahrnut v samostatné části níže, nicméně pro úplnost zahrnu stručný popis i zde. Utajovaný patent je standardním patentem mimo to, že je obsah jeho přihlášky po udělení ochrany zveřejněn $\mathrm{v}$ patentovém rejstř́iku. Takovým způsobem je i ve zkratce definován v § 71 patentového zákona - „pro ř́zení o vynálezech, které jsou utajovány podle zvláštního právního předpisu, nebo mezinárodní smlouvy, již je Česká republika vázána, platí tento zákon s výjimkou jejich zveřejnění". ${ }^{5}$ Znamená to tedy, že je vynálezci tohoto patentu poskytnuta veškerá ochrana související s udělením patentu, nicméně satisfakce veřejnosti v podobě uveřejnění jeho detailní podstaty se neodehraje. Nebo slovy teorie společenské smlouvy, ${ }^{6}$ druhá strana závazku se neuskuteční a jedná se tudíž pouze o smlouvu jednostrannou; tato smlouva veřejnosti nepřináší profit $\mathrm{z}$ přispění do obecného povědomí o technologickém vývoji.

Otázkou tedy zůstává, co lze považovat za užitek, který přináší společnosti patent, který zůstane utajovaný.

Intuitivní odpověd' bychom mohli najít $\mathrm{v} \S 2$ písm. a) a b) zákona č. 412/2005 Sb., o ochraně utajovaných informací a o bezpečnostní způsobilosti, ve znění pozdějších předpisů (dále jen "zákon o ochraně

\footnotetext{
MAZZOLENI, Roberto; NELSON, Richard. The benefits and costs of strong patent protection: a contribution to the current debate. Research Policy [online]. 1998, vol. 27, no. 3, s. 273 [cit. 6. 1. 2018].

5 Ustanovení § 71 patentového zákona.

6 Teorie společenské smlouvy s ohledem na patentovou ochranu byla uvedena ve zprávě francouzskému Národnímu shromáždění již v roce 1790 De Boufflerem; ve Francii se těšila oblibě, jedním z dalších zastánců byl i francouzský ekonom Louis Wolowski, který jej rozvedl ve své práci „Annales de la Société d’Economie Politique, VIII (1869-70)“. Viz MACHLUP, Fritz; PENROSE, Edith. The Patent Controversy in the Nineteenth Century. The Journal of Economic History [online]. 1950, vol. 10, no. 1, s. 26 [cit. 6. 1. 2018].
} 
utajovaných informací”). ${ }^{7}$ Utajovaná informace, která je součástí utajované patentové přihlášky, se nějakým způsobem podílí na zachování zájmů České republiky uvedených $\mathrm{v}$ písm. b) uvedeného ustanovení a současně její vyzrazení nebo zneužití podle písm. a) téhož ustanovení by způsobilo újmu na výše uvedených zájmech České republiky. ${ }^{8}$ Jedná se o zachování tzv. nedistributivních práv, což jsou "veřejné statky, pro které je typické, že prospěch z nich je nedělitelný a lidé nemohou být vyloučení z jeho požívání, př̌klady verejných statků jsou národní bezpečnost, verejný pořádek, zdravé životní prostředí", jak uvádí v odlišném stanovisku k nálezu Ústavního soudu č. j. Pl. ÚS 32/95 Pavel Höllander. ${ }^{9}$ Znamená to, že ačkoliv se takového zájmu nemůžeme domáhat jednotlivě, zájem na zachování těchto práv má každý. Můžeme tedy říci, že protiplněním za patentovou ochranu utajovaného vynálezu je přispění $\mathrm{k}$ ochraně zájmů České republiky.

Problematickou otázkou, která se téměř vždy naskytne, pokud argumentujeme "zájmy státu", je pak otázka určité hranice - jak lze oddělit, co ještě slouží přímo zájmům státu a co už ne? V otázce utajovaných patentů bych kontrolními body nazvala zejména to, že stupeň utajení navrhuje a priori sám přihlašovatel vynálezu, ${ }^{10}$ dále také možnost přezkumu rozhodnutí o udělení či neudělení navrhovaného stupně utajení, které probíhá standardně podle správního řádu ${ }^{11}$ či soudního řádu správního. ${ }^{12}$ Dále však detailně tento proces rozeberu v následující části.

Cílem této části byl stručný teoretický úvod do patentového práva se zaměřením na jeden $\mathrm{z}$ jeho důležitých principů - princip veřejnosti, který je $\mathrm{v}$ př́padě utajovaného patentu úplně potlačen, a definování základních rozdílů utajovaného patentu od patentu standardního.

7 Ustanovení § 2 písm. a) a b) zákona č. 412/2005 Sb., o ochraně utajovaných informací a bezpečnostní způsobilosti, ve znění pozdějších předpisů.

8 Tamtéž § 2 písm. a).

9 Bod 2 odlišného stanoviska Pavla Höllandera k nálezu pléna Ústavního soudu ze dne 3. 4. 1996, sp. zn. Pl. ÚS 32/95.

${ }^{10}$ V některých případech jej může navrhnout i zaměstnanec Úřadu, viz ustanovení čl. 8 odst. 8 Bezpečnostního řádu Úřadu průmyslového vlastnictví ve znění Př́íkazu č. 6 ze dne 31. 1 . 2012 (dále jen „Bezpečnostní řád“).

11 Zákon č. 500/2004 Sb., správní řád, ve znění pozdějších předpisů.

12 Zákon č. 150/2002 Sb., soudní řád správní, ve znění pozdějších předpisů. 


\subsection{UTAJOVANÁ INFORMACE V ČESKÉM PRÁVNÍM SYSTÉMU}

Již výše bylo uvedeno, že utajovaný patent je ten, který obsahuje utajované informace. Proto se tato část př́spěvku bude nejprve zabývat problematikou utajovaných informací obecně, ale i v kontextu s ochranou práv průmyslového vlastnictví. Definován bude zejména pojem utajované informace a analýza tuzemské právní úpravy nakládání s ní.

Jedná se o jakýkoliv druh informace, který je nutno ve veřejném zájmu utajit; $\mathrm{k}$ tomu je nutno splnit kumulativně tři podmínky uvedené $\mathrm{v} \S 2$ písm. a) zákona o utajovaných informacích. Informace musí být "označena způsobem stanoveným zákonem, ${ }^{13}$ jejǐž vyzrazení nebo zneužití může způsobit újmu zájmu České republiky nebo může být pro tento zájem nevýhodné $e^{14}$ a která je uvedena na seznamu utajovaných informací vydaném nařízením vlády", ${ }^{15}$ který upravuje § 139 tohoto zákona.

První podmínka - označování utajovaných informací podle zákona - je popsána ve IV. hlavě zákona o utajovaných informacích ${ }^{16}$ a prováděna vyhláškou č. 275/2015 Sb. ${ }^{17} \mathrm{~V} \S 21$ je pak specifikováno, jak má být utajovaná informace označena - musí být uveden název původce, stupeň utajení, evidenční značení a datum vzniku. ${ }^{18}$ Definici původce pak najdeme v § 2 písm. f) zákona o utajovaných informacích - jedná se o "orgán státu, právnická nebo podnikající fyzická osoba, u nichž utajovaná informace vznikla, nebo Úr̆ad průmyslového vlastnictví"19 (právě Úřad průmyslového vlastnictví bude původcem utajované informace podle tohoto zákona $v$ případě některých utajovaných patentových přihlášek, viz níže). ${ }^{20}$

Stupeň utajení stanovuje původce při vzniku informace a musí být zachován po celou dobu trvání důvodů utajení, přičemž původce musí prověřit aktuálnost důvodů pro utajení informace nejméně jednou za pět let -

\footnotetext{
13 Ustanovení § 21 zákona o ochraně utajovaných informací.

14 Zájmy České republiky jsou vyjádřeny tamtéž v § 2 písm. b).

15 Tamtéž § 2 písm. a).

16 Tamtéž § 21 a násl.

17 Vyhláška č. 275/2015 Sb., kterou se mění vyhláška č. 529/2005 Sb., o administrativní bezpečnosti a o registrech utajovaných informací, ve znění pozdějších předpisů.

18 § 21 zákona o ochraně utajovaných informací.

19 Tamtéž § 2 písm. f).
} 
pokud už důvody utajení stupni neodpovídají, je stupeň změněn nebo zrušen. ${ }^{21}$ Stupně utajení jsou vyznačeny v $§ 5$ zákona o ochraně utajovaných informacíi ${ }^{22}$ a ve vyhlášce o administrativní bezpečnosti jako PŘísNĚ TAJNÉ (zkratka “PT"), TAJNÉ (zkratka “T"), DŮVĚRNÉ (zkratka “D”) a VYHRAZENÉ (zkratka " $V$ "). ${ }^{23}$ Jedná se o čistě formalistickou podmínku, která ad absurdum říká, že označení utajované informace je nezbytnou podmínkou pro určení, že je informace utajovaná - a contrario informaci, která by fakticky měla být utajovaná, jelikož splňuje další dvě podmínky, avšak by z nějakého důvodu takto označena nebyla, by pak nebylo možno považovat za utajovanou a tudíž by byla veřejnosti přístupná, což by mohlo být proti zájmům České republiky. $\mathrm{V}$ tomto bodu se patrně jedná o neštastné vyjádření, jelikož z teleologického hlediska nelze tento postup považovat za zamýšlený zákonodárcem při tvorbě tohoto zákona. ${ }^{24} \mathrm{Na}$ tomto místě je na závěr ještě nutné dodat, že nevyznačení informace jako utajované je správním deliktem podle $\S 152$ odst. 1 písm. g) zákona o utajovaných informacích. ${ }^{25}$

Utajovaná informace musí dále mít tu vlastnost, že její “vyzrazení nebo zneužití může způsobit újmu zájmu České republiky nebo může být pro tento zájem nevýhodné". ${ }^{26}$ Seznam zájmů České republiky pak můžeme najít v $§ 2$ písm. b) zákona v taxativním výčtu - „zachování ústavnosti, svrchovanosti a územní celistvosti, zajištění vnitřního pořádku a bezpečnosti, zajištění mezinárodních závazků a obrany, ochrana ekonomiky a ochrana života nebo zdraví fyzických osob". ${ }^{27}$ Újmy jsou pak podle závažnosti rozděleny na čtyři katego-

20 Je třeba rozeznávat původce utajované informace podle zákona o utajovaných informacích a původce vynálezu podle zákona o vynálezech. Úřad průmyslového vlastnictví bude původcem dle zákona o ochraně utajovaných informací v případě, že přihlašovatelem utajovaného patentu bude fyzická nepodnikající osoba (viz. § 70 odst. 4 zákona o ochraně utajovaných informací).

21 Tamtéž $\S 22$.

22 Tamtéž $\S 5$.

23 § 4 vyhlášky č. 529/2005 Sb.

${ }^{24}$ K § 21 až 23. Důvodová zpráva k zákonu č. 412/2005 Sb. o ochraně utajovaných informací a o bezpečnostní způsobilosti.

25 Tamtéž $§ 152$ odst. 1 písm. g).

26 Tamtéž § 2 písm. a).

27 Tamtéž $\S 2$ písm. b). 
rie - mimořádně vážná, vážná, prostá újma a nevýhodnost pro zájmy, ${ }^{28}$ které hierarchicky kopírují rozdělení kategorií utajovaných informací (vyzrazení př́sně tajné informace může zapříčinit mimořádně vážnou újmu atd.). ${ }^{29}$

Poslední podmínka zmiňuje seznam utajovaných informací, v němž musí být informace uvedena. Seznam vydává vláda na základě § 139 odst. 1 zákona o utajovaných informacích. Proto jeho konkrétní podobu pak upravují nařízení vlády č. 522/2005 Sb. ${ }^{30}$ a č. 240/2008 Sb. ${ }^{31}$ Na vytváření seznamu se dále podílí Národní bezpečnostní úřad. ${ }^{32}$ Tento seznam obsahuje velmi obecné kategorie utajovaných informací a př́islušný stupeň utajení - často vyjádřen rozmezím stupňů. ${ }^{33}$ Jednotlivé instituce pak mohou vydat vlastní specifické vnitřní předpisy (např. bezpečnostní řád či metodický pokyn), ${ }^{34}$ které specifikují kategorie seznamu (např. Bezpečnostní rád stanoví, že v přihláškách vynálezů mohou být utajované informace pouze ve stupních Vyhrazené až Tajné, viz následující část ${ }^{35}$ ).

Posledním důležitým aspektem utajovaných informací, který je vhodné zmínit, je jejich rozdělení v § 5 zákona o utajovaných informacích ${ }^{36}$ podle zajištění ochrany těchto informací na personální, průmyslovou, administrativní a fyzickou bezpečnost, bezpečnost informačních a komunikačních systémů a kryptografickou ochranu. Pro účely této práce bude důležitá zejména personální bezpečnost, která stanovuje podmínky přistupu fyzické soby k utajovaným informacím a administrativní bezpečnost, která popisuje způ-

\footnotetext{
28 Tamtéž § 3.

29 Tamtéž $\S 4$.

30 Nařízení vlády č. 522/2005 Sb., kterým se stanoví seznam utajovaných informací, ve znění pozdějších předpisů.

31 Nařízení vlády č. 240/2008 Sb., kterým se mění nařízení vlády č. 522/2005 Sb., kterým se stanoví seznam utajovaných informací, ve znění pozdějších předpisů.

32 Ustanovení § 139 odst. 1 zákona o ochraně utajovaných informací.

33 Např. Nařízení vlády č. 522/2005 Sb., příloha I.

34 Bezpečnostní řád a Metodický pokyn pro řízení před Úřadem průmyslového vlastnictví z ledna 2016, část B (dále jen „Metodický pokyn“).

35 Ustanovení čl. 2 odst. 2 Bezpečnostního řádu.

36 Ustanovení § 5 zákona o ochraně utajovaných informací.
} 
sob fyzického nakládání s utajovanými informacemi. ${ }^{37}$ Zajištění jednotlivých druhů ochrany informací je pak specifikováno ve vyhláškách Národního bezpečnostního úřadu - konkrétně tedy vyhláška č. 363/2011 Sb., o personální bezpečnosti a vyhláška č. 529/2005 Sb., o administrativní bezpečnosti.

\subsection{UTAJOVANÝ PATENT}

Jak už bylo výše uvedeno, utajovaný patent je ve své podstatě patent obsahující utajované informace. Jedná se o institut, o kterém toho bohužel nevyčteme příliš ani ze zákona či podzákonných předpisů, ani z odborné literatury. Tato situace je samozřejmě kumulací několika různých důvodi̊, mám ale za to, že dva důvody jsou nejvýznamnější - zejména je patrné, že faktická data o aktuálních počtech takových patentů či jiné statistiky nejsou veřejně dostupné $\mathrm{k}$ analýze a za druhé se $\mathrm{v}$ České republice nejedná o nějaké velké téma či palčivý problém, jako je tomu jinde na světě. Pro představu jde na obranu, kde by se dal očekávat největší zájem o utajování vynálezů, za rok 2017 asi 1\% hrubého domácího produktu, ${ }^{38}$ což je jedna polovina závazku, který pro Českou republiku vyplývá ze členství v NATO. $^{39}$

Jinou pozitivní příčinou může být samozřejmě také poměrně dlouhá doba bez reálné válečné hrozby, nebot je historickou zkušeností, že technologický vývoj (a to nejen ten související s obranou státu) se významně zrychluje během válečných etap. ${ }^{40}$

Utajovaný patent je tedy taková patentová ochrana, která je využitelná na vynález, jehož podstata či část je utajovanou informací. Znamená to tedy, že by mohl být využit za účelem zachování zájmů České republiky tak, jak jsme si je definovali v předchozí části tohoto příspěvku - tedy

37 Tamtéž $§ 5$ písm. a) a c).

38 Resortní rozpočet. Ministerstvo obrany České republiky [online]. Copyright (C) Ministerstvo obrany, publikováno 26. června 2017 [cit. 25. 2. 2018].

39 NATO uklidňuje Trumpa, výdaje rostou. Česko je čtvrté od konce. iDnes.cz [online]. (C) MAFRA 1999 - 2018, publikováno 13. března 2017 [cit. 25. 2. 2018].

40 RUTTAN, Vernon W. Is War Necessary for Economic Growth?: Military Procurement and Technology Development. B.m.: Oxford University Press, 2006. s. 4 [cit. 25. 2. 2018]. 
ústavnosti, svrchovanosti a územní celistvosti, zajištění vnitřního pořádku a bezpečnosti, zajištění mezinárodních závazků a obrany, ochrana ekonomiky, ochrana života nebo zdraví fyzických osob. ${ }^{41}$ Prakticky tedy presumuji, že se bude jednat zejména o vynálezy, jejichž podstatu by mohly využít např́iklad zpravodajské služby, armáda České republiky, policejní sbory či celní správa při ochraně těchto zájmů.

Takový patent musí splnit standardně všechny zákonné podmínky podle zákona o vynálezech, rozdílné bude zejména "přiřazení” stupně utajení, úkony jednotlivých subjektů a následné nakládání s právy vyplývajícími z patentové ochrany.

\subsubsection{PRAMENY PRÁVNÍ ÚPRAVY}

Jak už bylo uvedeno výše, právní úprava obsahující přímo problematiku utajovaného patentu a nakládání s ním v českém právním řádu (mimo pár zmínek) neexistuje; častěji se setkáme spíše s průnikem práva ochrany utajovaných informací a patentového práva. Můžeme říci, že se jedná o institut na pomezí veřejného a soukromého práva - výsledky tvưrčí činnosti vynálezce, ke kterým má výlučná práva, se stávají utajovanou informací, což je z podstaty veřejnoprávní institut, ve veřejném zájmu (viz výše).

$\mathrm{Na}$ úrovni mezinárodních smluv je upravena otázka vzájemné ochrany utajovaných vynálezů Dohodou NATO o vzájemném zabezpečení utajení vynálezů týkajících se obrany, na něž byla podána žádost o udělení patentu („NATO Agreement for the mutual safeguarding of secrecy of inventions relating to defence and for which applications for patents have been made" dále jen „Dohoda NATO o vzájemném zabezpečení utajení vynálezư“) ${ }^{42}$ z 21. září 1960 (podepsána v Paříži) a ke které přistoupila Česká republika až 11. října 2000. Jejím účelem bylo zejména odstranit překážky v přihlašování utajovaných patentů v různých státech $\mathrm{NATO}^{43}$ - nutno dodat, že v době

\footnotetext{
41 Ustanovení $§ 2$ písm. b) zákona o ochraně utajovaných informací.

42 Sdělení Ministerstva zahraničích věcí č. 17/2003 Sb. m. s., o sjednání Dohody o vzájemném zabezpečení utajení vynálezů týkajících se obrany, na něž byla podána žádost o udělení patentu, ve znění pozdějších změn.

43 Ustanovení čl. 1 Dohody NATO o vzájemném zabezpečení utajení vynálezů.
} 
vzniku této smlouvy ještě neexistovala Smlouva o patentové spolupráci ${ }^{44}$ („Patent Cooperation Treaty“, nebo „PCT“, která vznikla až roku 1970) a nebylo tudíž možno přihlašovat vynálezy jednou mezinárodní přihláškou. Z textu Dohody NATO o vzájemném zabezpečení utajení vynálezů vyplývá, že předchozí praxe zakládajících států této dohody obvykle zakazovala utajovaný patent přihlásit i v jiných členských státech NATO, což brzdilo výzkum a vývoj na poli vojenské techniky. ${ }^{45}$ Jejím účelem je tedy umožnit přihlašovat utajované vynálezy u ostatních členských států a garantovat ochranu utajovaných informací, které přihláška obsahuje, v ostatních členských státech pod alespoň srovnatelným stupněm utajení jako v zemi původu. ${ }^{46}$

Žádná jiná z výše uvedených mezinárodních smluv o patentové ochraně problematiku utajovaného patentu neobsahuje.

Na evropské úrovni také samostatnou právní úpravu nenacházíme, což platí stejně jako pro národní právní systém. Úmluva o udělování evropských patentů pouze stanovuje ve svém čl. 77, že „evropská patentová přihláška, jejiž předmět byl utajen, se Evropskému patentovému úřadu nepředáváa, ${ }^{47} \mathrm{z}$ čehož vyplývá, že utajované přihlášky řeší vždy výhradně národní patentový úřad. $Z$ tohoto článku následně vyplývá, že při předávání přihlášek Evropskému patentovému úřadu má národní patentový úřad postupovat co nejrychleji, ovšem v respektu k lhůtám, které národní právní systém přiznává $\mathrm{k}$ průzkumu, zda předmět nepodléhá utajení. ${ }^{48}$

Důvodem absence mezinárodní i evropské úpravy je pak zejména fakt, že se jedná o problematiku téměř výhradně teritoriálního charakteru (což

\footnotetext{
${ }^{44}$ Sdělení federálního ministerstva zahraničních věcí č. 296/1991 Sb., o uložení listiny o přístupu České a Slovenské Federativní Republiky ke Smlouvě o patentové spolupráci, sjednané ve Washingtonu dne 17. června 1970, ve znění pozdějších změn.

45 Ustanovení čl. 1 Dohody NATO o vzájemném zabezpečení utajení vynálezů.

${ }^{46}$ Ustanovení čl. 10 Dohody NATO o vzájemném zabezpečení utajení vynálezů, omezení přihlašování utajovaných vynálezů $\mathrm{v}$ zahraničí je stále součástí komparovaných právních úprav, viz níže.

${ }^{47}$ Ustanovení čl. 77 odst. 2 Sdělení Ministerstva zahraničních věcí č. 69/2002 Sb. m. s., o přístupu České republiky k Úmluvě o udělování evropských patentů (Evropské patentové úmluvě), ve znění pozdějších změn.

48 Tamtéž.
} 
vyplývá ze samotné podstaty „utajování“ informací, či patentů, v rámci zachování zájmů státu).

Utajovaný patent na národní úrovni vychází z právní úpravy patentových práv a ochrany utajovaných informací, znamená to tedy, že se jedná o kombinaci právních pramenů uvedených výše. Na zákonné úrovni se jedná o zákony č. 527/1990 Sb., o vynálezech a zlepšovacích návrzích a č. 412/2005 Sb., o ochraně utajovaných informací. Dále se na něj vztahují ještě podzákonné předpisy Úřadu průmyslového vlastnictví, zejména Bezpečnostní řád a Metodický pokyn Úřadu průmyslového vlastnictví, a taktéž podzákonné předpisy Národního bezpečnostního Úřadu, např. výše zmiňovaná vyhláška o administrativní bezpečnosti a další.

Při analýze situace de lege lata tak budu vycházet zejména z patentového zákona, jelikož je právní úprava z velké části totožná s právní úpravou veřejného patentu, ${ }^{49}$ zejména $\mathrm{v}$ oblasti obecných zásad a principů patentové ochrany, které byly uvedeny výše, či předmětu ochrany, zúčastněných subjektů nebo podmínek ochrany. $\mathrm{V}$ částech týkajících se řízení o udělení patentové ochrany či vymahatelnosti práv pak budu více vycházet ze zákonné úpravy ochrany utajovaných informací, ${ }^{50}$ kterou se obsah patentové přihlášky stává v momentě udělení stupně utajení.

Samotný zákon o vynálezech předpokládá existenci utajovaných vynálezů na jediném místě - v $\$ 71$ určuje použití tohoto zákona i na vynálezy utajované $s$ vyjímkou jejich zveřejnění. ${ }^{51}$ Mohli bychom tedy říci ve vztahu k standardnímu patentu, že ten utajovaný je speciálním druhem patentu, na který lze použít všechna zákonná pravidla obsažená v patentovém zákoně s výjimkou zveřejnění, které koliduje s ochranou utajovaných informací dle zákona. ${ }^{52}$ Domnívám se nicméně, že tohle pravidlo lze zobecnit; $\mathrm{z}$ úpravy ochrany utajovaných informací zákonem vyplývají i další povinnosti pro nakládání s utajovanými informacemi - např. zachování mlčenlivosti, ${ }^{53}$

\footnotetext{
49 Ustanovení § 71 patentového zákona.

50 Zejména ze zákona o ochraně utajovaných informací a z příslušných podzákonných předpisů (např. vyhláška č. 529/2005 Sb., atd.).

51 Ustanovení § 71 patentového zákona.

52 Zákon o ochraně utajovaných informací.

53 Ustanovení § 65 odst. 2 zákona o ochraně utajovaných informací.
} 
z toho lze vyvodit, že je nutné při nakládání s utajovaným patentem vycházet primárně ze zákona o ochraně utajovaných informací a zejména $\mathrm{v}$ případech, kdy by ustanovení kolidovala s ustanoveními patentového zákona.

\subsection{PŘEDMĚT OCHRANY}

Otázka předmětu ochrany patentovým právem je jedna z těch, které jsou totožné u utajovaného i veřejného patentu, proto se mu budu věnovat jen krátce, vzhledem k hojnosti relevantní literatury. ${ }^{54}$

Právo na ochranu vynálezi̊, neboli patentové právo, upravuje právní vztahy vznikající při institucionální ochraně průmyslového vlastnictví. Subjekty těchto vztahů jsou původce, přihlašovatel a majitel patentu, objektem jsou vztahy vznikající z ochrany a předmětem je samotný vynález. ${ }^{55}$ Úřad průmyslového vlastnictví je správním orgánem pro patentové řízení ${ }^{56}$ a Národní bezpečnostní úřad je zase správním orgánem pro otázky související s utajováním informací. ${ }^{57}$

Vynález je tedy ústředním pojmem patentového práva, místo legální definice tohoto pojmu obsahuje zákon hmotněprávní podmínky, za kterých je možné vynález patentovat - tzv. podmínky patentovatelnosti. ${ }^{58}$ Definici dále doplňuje negativně vymezený seznam předmětů, které nelze patentovat. $^{59}$

54 Např. JAKL, Ladislav. Právní ochrana vynálezů a užitných vzorů: vypracování jejich popisů a nároků na ochranu. 1. vyd. Praha: Metropolitní univerzita Praha, 2010, s. 11 - 21, POSPÍŠIL, Michal a kol. Práva z průmyslového vlastnictví. 1. vyd. Praha: Vysoká škola aplikovaného práva, 2007, s. 20 - 22, TAKENAKA, Toshiko. Patent law and theory: a handbook of contemporary research. Cheltenham, UK: Edward Elgar, 2008. Research handbooks in intellectual property. s. 325 - 414, HORÁČEK, Roman a kol. Práva k průmyslovému vlastnictví. 3. dopl. a přeprac. vyd. Praha: C.H. Beck, 2017, s. 80 - 90.

55 Nutno řádně rozlišovat pojmy vynález, což je samotný předmět ochrany, tedy nové technické řešení, a patent, což je udělená právní ochrana; bývá veřejností zaměňováno.

56 § 2 patentového zákona.

57 § 136 zákona o ochraně utajovaných informací.

58 § 3 patentového zákona.

59 Jsou jimi „objevy, vědecké teorie a matematické metody, estetické výtvory, plány pravidla azpůsoby vykonávání duševní činnosti, hraní her nebo vykonávání obchodní činnosti, programy počítačů a podávání informací" uvedeny v $§ 2$ odst. 3 tamtéž. 


\subsubsection{PODMÍNKY PATENTOVÉ OCHRANY}

Podmínky patentovatelnosti jsou obecně uvedeny v § 3 zákona o vynálezech a platí stejně pro utajované patenty. Jedná se o „novost, výsledek vynálezecké činnosti a průmyslovou využitelnost“ “. ${ }^{60}$

Zákon stanovuje, že „vynález je nový, není-li součástí stavu techniky“. ${ }^{61}$ Pojem „stav techniky“ pak definuje v odstavci druhém, kde uvádí, že se jedná o „,še, $k$ čemu byl přede dnem, od něhož př̌sluši přihlašovateli právo přednost, umožněn př́stup veřejnosti“ ${ }^{62}$ Obsah patentové přihlášky, u které je podána žádost na utajení, se však nezveřejňuje, což vyplývá ze zákona ${ }^{63}$ i ze samotné podstaty utajovaného patentu. Zůstává tedy otázka, zda i obsahy utajovaných přihlášek jsou součásti stavu techniky. Tato otázka je řešena v § 5 odst. 3, který říká, že „přihlášky vynálezů utajované podle zvláštních předpisů se pokládají pro účely tohoto ustanovení za zveřejněné uplynutím 18 měsíců od vzniku práva přednosti“ ${ }^{64} \mathrm{Z}$ hlediska právní teorie se bude jednat o právní fikci - je patrné, že zveřejnění utajované přihlášky nikdy nenastane (pouze $\mathrm{v}$ moment odtajnění, kdy už se ale nebude jednat o utajovanou přihlášku), znamená to tedy, že se nelze dovolat opaku. Druhý závěr který lze vyvodit je ten, že součástí úplného průzkumu přihlášky ke zjištění současného stavu techniky je i průzkum utajovaných vynálezů.

To přináší dvě zajímavé otázky - nejprve otázku personální bezpečnosti státních úředníků na Úřadě průmyslového vlastnictví, z nichž někteří pro vypracování rešerše současného stavu techniky musí být držiteli platného osvědčení fyzické osoby pro prrístup k utajovaným informacím daného stupně.

Dále v př́padě, že by byl obsah zkoumané přihlášky, i částečně, totožný s obsahem některé přihlášky utajované a zkoumaná přihláška by proto byla zamítnuta z důvodu, že by nesplňovala podmínku novosti, musí zamítnutí

\footnotetext{
60 Tamtéž § 3.

61 Tamtéž $§ 5$ odst. 1.

62 Tamtéž $§ 5$ odst. 2.

63 Tamtéž § 71.

64 Ustanovení § 5 odst 3 patentového zákona.
} 
obsahovat zákonné náležitosti dle $\S 34$ odst. 1 zákona o vynálezech, který stanoví, že „pred zamítnutím přihlášky vynálezu musí být přihlašovateli umožněno vyjádrìt se $k$ podkladům, na jejichž základě má být o přihlášce vynálezu rozhodnuto “ ${ }^{65} \mathrm{Z}$ toho vyplývá, že nastane konflikt práva přihlašovatele na vyjádření se $\mathrm{k}$ důvodům zamítnutí s ochranou utajovaných informací, kterou je obsah utajovaného patentu. Řešení nabízí zákon o ochraně utajovaných informací konkrétně v $§ 58$ odst. 4, který určuje, že pro účel trestního, správního a občanského řízení okruh osob, které mají př́stup k utajovaným informacím bez platného osvědčení, určí zvláštní předpis. ${ }^{66}$ Správní řád dále uvádí, že $\mathrm{v}$ případě, že jsou součástí podkladů $\mathrm{k}$ rozhodnutí utajované informace, tak se s nimi může účastník seznámit tak, aby to nezmařilo účel utajení; pokud by to nebylo možné, tak orgán sdělí účastníkovi alespoň obecně, jaké skutečnosti z nich vyplývají. ${ }^{67}$ Tato právní úprava však byla do zákona vložena až novelou zákonem č. 183/2017 Sb., ${ }^{68}$ důvodová zpráva uvádí, že „v rízeních, kde se rozhoduje o právním nároku, je žádoucí, aby osoba měla př́stup $k$ podkladům pro rozhodnutí (alespoň $v$ agregované podobě), na rozdíl od ř́zení, kde se o jejím právním nároku nerozhoduje“ ${ }^{69}$ Navazuje tak na nález Ústavního soudu ze dne 16. června 2011, který stanovuje, že „pokud by vůbec nebylo možné poskytnout žalobci př́stup $k$ utajovaným informacím byt'v určité omezené formě, není soud vázán žalobními body a přezkoumá relevanci utajovaných informací ze všech hledisek, která se vzhledem $k$ povaze věci jeví důležitými, [...], z toho plyne, že rozhodnutí, $v$ jehož odůvodnění budou pouze $v$ obecné rovině skutečnosti, které vyplývají z podkladů obsahujicích utajované informace, bude přezkoumatelné podle $\S 76$ odst. 1 písm. a) soudního řádu správního, resp. ve smyslu čl. 38 odst. 2 Listiny

65 Tamtéž § 34 odst. 1.

66 Zvláštním předpisem je v této situaci zákon č. 500/2004 Sb, správní řád, který je subsidiárním aplikačním předpisem pro řízení před Úřadem průmyslového vlastnictví (pokud jeho použití není zákonem vyloučeno) podle $\S 63$ odst. 1 patentového zákona.

67 § 36 odst. 3 zákona č. 500/2004 Sb.

68 Zákon č. 183/2017 Sb., kterým se mění některé zákony v souvislosti s přijetím zákona o odpovědnosti za přestupky a řízení o nich a zákona o některých přestupcích, ve znění pozdějších předpisů.

69 Důvodová zpráva k zákonu č. 183/2017 Sb. 
základních práv a svobod““ ${ }^{70}$ Výše uvedené pak znamená, že pakliže účastník nemá možnost zúčastnit se s podklady, které vedly $\mathrm{k}$ napadanému rozhodnutí z důvodu, že obsahují utajované informace, tak soud má povinnost provést $\mathrm{v}$ navazujícím řízení úplný přezkum podkladů rozhodnutí.

Dále musí vynález splnit podmínky výsledku vynálezecké činnosti a průmyslové využitelnosti, tyto podmínky jsou uvedeny v $\quad$ 6 a $\quad \S 7$ zákona o vynálezech - pokud je vynález výsledkem vynálezecké činnosti, znamená to, že „pro odborníka nevyplývá zřejmým způsobem ze stavu techniky“"71, průmyslové využitelný je, „může-li jeho předmět být vyráběn nebo jinak využíván $v$ průmyslu, zemědělství nebo jiných oblastech hospodárstvi“" ${ }^{\prime 2}$. Obě tyto podmínky se pro utajované patenty nebudou samožrejmě nijak lišit. ${ }^{73}$

\subsection{SUBJEKTY}

Zákon definuje tři typy subjektů patentových práv - původce vynálezu, jeho přihlašovatele a majitele. Za určitých okolností můžeme uvažovat i spolupůvodce, a to $\mathrm{v}$ případě, že se na tvưrčí činnosti vedoucí $\mathrm{k}$ vynálezu podílela více než jedna osoba. ${ }^{74}$

Původce je fyzická osoba, která svojí tvưrčí prací vytvořila vynález. ${ }^{75}$ Přihlašovatel je dále ten, kdo podal patentovou přihlášku $\mathrm{k}$ Úřadu průmyslového vlastnictvi ${ }^{76}$ a majitel je ten, kdo má výlučná práva disponovat s patentem. ${ }^{77}$

$\mathrm{V}$ př́padě, že bude patentová přihláška označena za utajenou a bude tedy obsahovat utajenou informaci některého stupně, pak bude nakládání

\footnotetext{
70 Nález Ústavního soudu ze dne 16. června 2011 sp. zn. II. ÚS 1392/11.

$71 \S 6$ patentového zákona.

72 Ustanovení § 7 patentového zákona.

73 Pro účely této práce nejsou podmínky patentovatelnosti více rozebrány, dovoluji si odkázat na odbornou literaturu: CHLOUPEK, Vojtěch a kol. Patentový zákon. Komentář. 1. vydání. Praha: C. H. Beck, 2017, s. 6 - 18, nebo HORÁČEK, Roman a kol. Práva $k$ průmyslovému vlastnictví. 2., dopl. a přeprac. vyd. V Praze: C.H. Beck, 2011, s. 41-62 či KNAP, Karel a kol. Práva k nehmotným statkům. 1. vyd. Praha: Codex, 1994, s. 23-30.

74 Ustanovení § 8 odst. 3 patentového zákona.

75 Tamtéž $§ 8$ odst. 2.

76 Ustanovení § 24 zákona patentového zákona.

77 Tamtéž § 34 odst. 3.
} 
s ní podléhat režimu zákona o ochraně utajených informací; znamená to tedy, že pro přístup $\mathrm{k}$ takové informaci bude muset být osoba v roli jednoho ze subjektů řádně poučena (pokud neplňuje podmínky k přístupu už předtím). Poučení provádí Úřad průmyslového vlastnictví a to podle úpravy zákona č. 412/2005 Sb. ${ }^{78}$

Ačkoliv to ze zákona přímo nevyplývá, přístup k utajované informaci na základě $\S 70$ zákona o ochraně utajovaných informací lze analogicky přirovnat ke zvláštnímu př́stupu k utajované informaci podle $\S 58$ odst. 4 téhož zákona, který upravuje přístup fyzických osob bez platného osvědčení $\mathrm{k}$ utajovaným informacím $\mathrm{v}$ trestním řízení, $\mathrm{v}$ občanském soudním řízení, ve správním řízení a v soudním řízení správním pouze na základě jejich poučení. ${ }^{79}$ Toto lze usuzovat na základě toho, že řízení před Úřadem průmyslového vlastnictví je speciálním typem správního řízení, jak již bylo výše uvedeno, podle zákona o ochraně vynálezů se subsidiární aplikovatelností správního řádu. ${ }^{80} \mathrm{Z}$ toho vyplývá, ${ }^{81}$ že poučení bude provedeno povinnou osobou způsobem podle ustanovení § 2 písm. i) zákona o ochraně utajovaných informací - tedy „písemným záznamem o seznámeni fyzické osoby $s$ jejími právy a povinnostmi $v$ oblasti ochrany utajovaných informací a s následky jejich porušeni “ ${ }^{82}$ a to před prvním přístupem $\mathrm{k}$ informaci přiměřeně podle $\S 9$ odst. 1 téhož zákona. ${ }^{83}$

Pokud dojde k udělení utajovaného patentu a přihlašovatelem je nepodnikající fyzická osoba, má postavení původce utajované informace Úřad průmysového vlastnictví. ${ }^{84}$

\footnotetext{
78 Ustanovení $§ 70$ odst. 5 patentového zákona.

79 Ustanovení $§ 58$ odst. 5 zákona o ochraně utajovaných informací.

80 Ustanovení § 63 odst. 1 patentového zákona. K otázce se nevyjadřuje ani důvodová zpráva či některý z komentářů ke správnímu řádu.

81 Konkrétně analogicky z $§ 58$ odst. 5 zákona o ochraně utajovaných informací.

82 Ustanovení § 2 písm. i) zákona o ochraně utajovaných informací.

83 Tamtéž $§ 9$ odst. 1.

84 Tamtéž $§ 70$ odst. 4.
} 


\section{6 ŘÍZENÍ O UDĚLENÍ UTAJOVANÉHO PATENTU}

Během řízení o udělení utajovaného patentu, nebo-li o utajované patentové přihlášce, se nejvíce projevuje charakter utajované informace a její dopad na běžné patentové řízení.

V řízení o utajované přihlášce vystupují dvě důležité instituce - Úřad průmyslového vlastnictví a Národní bezpečnostní úřad, které spolu kooperují v případě přihlášek obsahujících utajované informace.

\subsubsection{POSTAVENÍ ÚŘADU PRŮMYSLOVÉHO VLASTNICTVÍ V ŘÍZENÍ}

Jelikož je řízení o udělení utajovaného patentu speciálním patentovým řízením, ve kterém dochází k nakládání s utajovanými informacemi, Úřad průmyslového vlastnictví proto zřizuje speciální pozice. Zákon o ochraně utajovaných informací ukládá všem orgánům státní správy, u kterých vzniká nebo kterým je poskytnuta utajovaná informace, zřízení institutu bezpečnostního ředitele. ${ }^{85}$

Bezpečnostní ředitel je obsazen předsedou Úřadu a zabezpečuje plnění povinností Úřadu vyplývajících ze zákona o ochraně utajovaných informací, tedy zejména těch, které vyplývají z řízení o utajované přihlášce; ${ }^{86}$ konkrétní povinnosti budou zmíněny u popisu příslušných částí řízení.

Dále se jedná o personál Úřadu podílející se nařízení o utajovaných přihláškách, Metodický pokyn či Bezpečností řád ÚPV pak zmiňují přímo zaměstnance patentového odboru, jež má přístup $\mathrm{k}$ utajovaným informacím, ${ }^{87}$ a který poté prakticky vede celé řízení o přihlášce a provádí, současně $\mathrm{s}$ bezpečnostním ředitelem, úkony $\mathrm{v}$ řízení.

Patentové řízení jako takové podléhá zásadě formálnosti, znamená to tedy, že Úřad průmyslového vlastnictví sám věcně zkoumá, zda byly splněny všechny podmínky podle zákona o vynálezech a podle toho udělí či neudělí patentovou ochranu. ${ }^{88}$ Dále vzhledem $\mathrm{k}$ tomu, že samotné řízení může

\footnotetext{
85 Ustanovení § 71 zákona o ochraně utajovaných informací.

86 Ustanovení čl. 4 odst. 2 Bezpečnostního řádu.

87 Ustanovení čl. 2.3 Metodického pokynu.

88 CHLOUPEK, Vojtěch a kol. § 24 [Zahájení ř́zení]. In: Patentový zákon. Komentář. 1. vydání. Praha: Nakladatelství C. H. Beck, 2017, s. 182.
} 
být pro Úřad průmyslového vlastnictví finančně i časově náročné, uplatní se zde i tzv. princip odloženého průzkumu, který znamená provedení průzkumu až v př́padě předpokladu, že patent bude opravdu udělen. ${ }^{89} \mathrm{Jak}$ již bylo výše zmíněno, na tato řízení se použije právní úprava zákona o vynálezech a o ochraně utajovaných informací se subsidiárním použitím správního řádu mimo taxativně vyjmenované instituty. ${ }^{90}$ Dále se na tento typ ř́zzení aplikuje vyhláška č. 550/1990 Sb., o řízení ve věcech vynálezů a užitných vzorů, vyhláška č. 527/2005 Sb., o administrativním značení utajovaných informací a dále několik interních předpisů jako je Metodický pokyn, Bezpečnostní řád či Instrukce předsedy Úřadu, kterou se stanoví standard úpravy přihlášky vynálezu. ${ }^{91}$

\subsubsection{UTAJOVANÁ PATENTOVÁ PŘIHLÁŠKA}

Utajovaná patentová přihláška musí formálně splňovat všechny zákonné náležitosti standardní přihlášky ${ }^{92}$ spolu s návrhem stupně utajení vynále$\mathrm{zu}^{93}$

Návrh na stupeň utajení má povinnost podat přihlašovatel $\mathrm{v}$ případě, že se domnívá, že přihláška obsahuje utajované informace. ${ }^{94}$ Zákon ani komentář tuto povinnost nespecifikují, lze tedy vycházet pouze z obecné zákonné definice utajované informace jak byla popsána výše, ${ }^{95}$ mělo by se tedy jednat o přihlášku na vynález, jehož zveřejnění by bylo proti zájmům České republiky. Odtajněné patentové přihlášky obsahují např́klad roz-

89 CHLOUPEK, Vojtěch a kol. § 33 [Úplný průzkum]. In: Patentový zákon. Komentář. 1. vydání. Praha: Nakladatelství C. H. Beck, 2017, s. 219.

90 Ustanovení $\S 63$ odst. 1 patentového zákona.

91 Instrukce předsedy Úřadu průmyslového vlastnictví ze dne 30. prosince 2009, kterou se stanoví standard úpravy přihlášky vynálezu, žádosti o udělení dodatkového ochranného osvědčení a přihlášky užitného vzoru.

92 Otázka formálních náležitostí patentových přihlášek je obsáhlou sama o sobě, v této práci se zaměřím spíše na její utajení. Pro srovnání však např. CHLOUPEK, Vojtěch a kol. § 24 [Zahájení ř́zení]. II. Obsah přihlášky. In: Patentový zákon. Komentář. 1. vydání. Praha: Nakladatelství C. H. Beck, 2017, s. 183 - 192, a HORÁČEK, Roman a kol. Práva k průmyslovému vlastnictví. 3. vydání. Praha: C. H. Beck, 2017, s. 129 - 140.

93 Ustanovení čl. 2.3 Metodického pokynu.

94 Ustanovení čl. 2.3 Metodického pokynu a § 70 odst. 1 zákona o ochraně utajovaných informací.

95 Ustanovení § 2 písm. a) zákona o ochraně utajovaných informací. 
nětku pro zapalovače, zážehovou směs, iniciační slož pro trasovací slož, hydraulickou zákluzovou brzdu s ventilem apod. ${ }^{96}$

$\mathrm{V}$ případě, že přihlašovatel tento návrh nepodá, může jej navrhnout i zaměstnanec Úřadu průmyslového vlastnictví a oznámit návrh bezpečnostnímu řediteli, domnívá-li se, že přihláška obsahuje utajovanou informaci. ${ }^{97}$ $\mathrm{V}$ praxi je však nejčastější situace, kdy je podán návrh stupně utajení přihlašovatelem, který je poté většinou odmítnut. ${ }^{98}$

Podáním přihlášky vzniká přihlašovateli právo priority, ${ }^{99}$ proto je okamžik podání důležitý; náležitosti podání přihlášky jsou alespoň označení přihlašovatele projevujícího vůli přihlásit vynález a popis vynálezu. ${ }^{100}$ Od tohoto momentu se také počítá osmnácti měsíční lhůta, po jejímž uplynutí je utajovaná přihláška považována za zveřejněnou pro účely určení stavu techniky, ${ }^{101}$ fakticky zveřejněna ale není.

\subsection{3 ŘÍZENÍ O UTAJOVANÉ PŘIHLÁŠCE}

Samotnému rrízení o přihlášce, tedy zjištování, zda-li přihláška splňuje formální požadavky definované zákonem o vynálezech, v př́ípadě utajované

96 Jedná se o odtajněné vynálezy, které byly zveřejněny ve věstníku po odtajnění pod kódem záhlaví podle WIPO standardu č. 17 „SB4A“ a „SB4F“ pro autorská osvědčení, která se již nepoužívají. Více ke zveřejňování ve Věstníku viz níže. (WIPO standard st. 17: Recommendation for the coding of headings of announcements made in official gazettes. Handbook on industrial property information and documentation [online]. World intellectual property organization [cit. 28. 2. 2018].). Jedná se o: SELLIER AND BELLOT A. S. VLAŠIM. Roznětka pro zapalovače. Původce: Václav SVACHOUČEK. Česká republika. Patentový spis CZ 299391 B6. 30. 1. 1997. SELLIER AND BELLOT A. S. VLAŠIM. Zážehová směs. Původce: Jiří NESVEDA, Stanislav BRANDEJS, Radek KOTOUČEK. Česká republika Patentový spis CZ 299392 B6. 13. 8. 1996. SELLIOR AND BELLOT A. S. VLAŠIM. Iniciační slož pro trasovací slož. Původce: Václav SVACHOUČEK. Patentový spis CZ 299393 B6. 21. 12. 1998. MINISTERSTVO OBRANY ČR, ODBOR VĚCNÝCH ZDROJŮ A SPRÁVY ORGANIZACÍ PRAHA. Hydraulická zákluzová brzda s ventilem. Původce: Milan VAŠíčEK, Josef MANĎÁK. Česká republika. Autorské osvědčení CZ 299396 B1. 22. 4. 1986.

97 Ustanovení čl. 8 odst. 6 Bezpečnostního řádu.

98 Tuto informaci poskytla ke zveřejnění $\mathrm{k}$ JUDr. Eva Maříková z Odboru právního a legislativního Národního bezpečnostního úřadu. Tímto bych jí chtěla poděkovat.

99 Více k právu přednosti např. HORÁČEK, Roman a kol. Práva $k$ průmyslovému vlastnictví. 3. vydání. Praha: C. H. Beck, 2017, s. 129.

${ }^{100}$ JAKL, Ladislav. Právní ochrana vynálezů a užitných vzorů: vypracování jejich popisů a nároků na ochranu. 1. vyd. Praha: Metropolitní univerzita Praha, 2010. s. 53.

${ }^{101}$ Ustanovení $§ 5$ odst. 2 patentového zákona. 
přihlášky předchází fáze, ve které se zjištuje, zda-li je návrh na stupeň utajení podaný at už přihlašovatelem či zaměstnancem Úřadu průmyslového vlastnictví důvodný. Nutno dodat, že tato fáze předchází i řízení odehrávající se na vstupním a poplatkovém odboru, má tedy absolutní prioritu. ${ }^{102}$ Současně v př́padě, že by se jednalo o evropskou či mezinárodní přihlášku s návrhem stupně utajení, ${ }^{103}$ musí být $\mathrm{k}$ samotnému podání této přihlášky přiložen souhlas Národního bezpečnostního úřadu. ${ }^{104}$ Takovýto případ však není znám v posledních letech ani jeden. ${ }^{105}$

$\mathrm{V}$ př́padě, že se jedná o přihlášku s návrhem na stupeň utajení podaným přihlašovatelem, pak bezpečnostní ředitel Úřadu průmyslového vlastnictví předloží tuto přihlášku bezodkladně Národnímu bezpečnostnímu úřadu, a to včetně popisu nároků, anotace a výkresů a vyobrazení. Národní bezpečnostní úřad rozhoduje o udělení stupně utajení tedy ještě před provedením předběžného průzkumu. $\mathrm{V}$ případě, že se jedná o přihlášku standardní tak $\mathrm{k}$ návrhu na stupeň utajení dojde projednávajícím zaměstnancem úřadu či bezpečnostním ředitelem až během předběžného průzkumu přihlášky.

Do doby rozhodnutí Národního bezpečnostního úřadu o stupni utajení je s přihláškou nakládáno, jakoby byla utajovanou informací stupně $V y$ hrazená. $^{106} \mathrm{~V}$ př́ípadě, že se jedná o přihlášku neobsahující návrh stupně utajení od přihlašovatele je do doby odtajnění utajované informace během př̀dběžného průzkumu a navrhnutí stupně utajení s přihláškou nakládáno standardně a poté jako s utajovanou informací stupně Vyhrazená.

Národní bezpečnostní úřad poté rozhoduje o návrhu stupně utajení; ve lhůtě 60 dní musí navrhovaný stupeň bud’ potvrdit, změnit či zamítnout, v praxi je údajně většina takovýchto návrhů zamítnuta. ${ }^{107}$ Rozhoduje však na základě vyjádření ústředního správního úřadu, do jehož věcné pů-

\footnotetext{
${ }^{102}$ Ustanovení čl. 8 odst. 2 Bezpečnostního řádu.

${ }^{103}$ Viz část 1.3 této práce.

${ }^{104}$ Ustanovení $\S 24$ odst. 4 patentového zákona.

105 Tuto informaci poskytla ke zveřejnění JUDr. Eva Maříková.

${ }^{106}$ Ustanovení čl. 7 odst. 3 zákona o ochraně utajovaných informací.

107 Tuto informaci poskytla ke zveřejnění JUDr. Eva Maříková z Odboru právního a legislativního Národního bezpečnostního úřadu. Tímto bych jí chtěla poděkovat.
} 
sobnosti spadá předmět přihlášky, např. u zbraňového systému by to typicky bylo Ministerstvo obrany, u ochranného prvku proti padělání bankovek by se jednalo o Českou národní banku atd. $V$ případě, že by předmět nespadal do věcné působnosti žádného takového orgánu, není vyjádření vyžadováno. ${ }^{108}$

Na základě tohoto vyjádření pak Národní bezpečnostní úřad rozhodne, zda přihláška utajovanou informaci obsahuje. Pokud je návrh na stupeň utajení zamítnut, přihláška se eviduje jako běžná a dále standardně pokračuje řízení o udělení patentu před Úřadem. Informace o zamítnutí návrhu na stupeň utajení je však zveřejněna $v$ patentové dokumentaci ve Věstníku a online databázi v přehledu položek řízení. ${ }^{109}$

$\mathrm{V}$ př́padě, že Národní bezpečnostní úřad rozhodne, že přihláška utajovanou informaci obsahuje, předá přihlášku zpět bezpečnostnímu řediteli, který ji spravuje následně ${ }^{110}$ spolu s informací, zda-li přihlašovatel splňuje podmínky př́stupu $\mathrm{k}$ utajované informaci daného stupně. ${ }^{111}$ Jeho povinností je uvědomit o tomtu faktu přihlašovatele a to opět bezodkladně a v písemné formě ${ }^{112}$ a zaznačit stupeň utajení na přihlášce, přihlašovatel pak musí označit stupeň utajení na předmětu přihlášky. Další povinností bezpečnostního ředitele je evidovat utajovanou přihlášku v protokolu ${ }^{113}$ postupem podle čl. 6 Bezpečnostního řádu. Obsah tohoto ustanovení vychází mimo jiné z vyhlášky Národního bezpečnostního úřadu č. 529/2005 Sb., o administrativní bezpečnosti a o registrech utajovaných informací a lze říci, že ji specifikuje a určuje konkrétní povinnosti pověřeným osobám (v daném případě bezpečnostnímu řediteli) ${ }^{114}$ což je i explicitně uvedeno

\footnotetext{
${ }^{108}$ Tuto informaci také poskytla ke zveřejnění JUDr. Eva Maříková z Odboru právního a legislativního Národního bezpečnostního úřadu. Tímto bych jí chtěla poděkovat.

${ }^{109}$ Např. ZVI A. S. PRAHA. Zážehová slož pro elektricky iniciovatelné zápalky. Původci: Václav SVACHOUČEK, Jan KUSÁK, Jiří STRNAD. Česká republika. Patentový spis CZ 295050 B6. 11. 3. 2005.

${ }^{110}$ Ustanovení čl. 2.3 Metodického pokynu.

${ }^{111} \S 70$ odst. 3 zákona č. 412/2005 Sb.

${ }^{112}$ Ustanovení čl. 8 odst. 1 Bezpečnostního řádu.

${ }^{113}$ Tamtéž čl. 8 odst. 2.

${ }^{114}$ Ustanovení $§ 1$ vyhlášky č. 529/2005 Sb.
} 
v čl. 5 odst. 1 Bezpečnostního řádu. ${ }^{115}$ Ustanovení popisuje konkrétní způsob označování utajovaných dokumentů a způsob vytvoření jednacího čísla, způsob evidování utajovaných přihlášek a vedení jejich spisů - tzv. spisovou službu, ${ }^{116}$ která je dále specifikována v čl. 9 Bezpečnostního řádu.

$\mathrm{V}$ př́padě klasické patentové přihlášky se po běžné evidenci a založení spisu přihlášky vynálezu tato přihláška naskenuje a zaznamená do databáze, což provádí vstupní oddělení Úřadu. ${ }^{117} \mathrm{~V}$ případě utajované přihlášky však bezpečnostní ředitel provede pouze omezený zápis bibliografických údajů do databáze, který obsahuje pouze spisovou značku, mezinárodní patentovou tř́du, datum podání přihlášky a kód utajovaných přihlášek. ${ }^{118}$ Bezpečnostní ředitel následně uchovává všechny utajované dokumenty v trezoru. ${ }^{119}$

Přihláška je po zaevidování předána do rukou té fyzické osobě na patentovém odboru Úřadu, která má př́stup k utajovaným informacím; tato osoba následně vede celé řízení o utajované přihlášce $\mathrm{v}$ zabezpečené oblasti ${ }^{120}$ (Metodický pokyn zmiňuje pouze „místnost $k$ tomu vhodnou ${ }^{\text {“121 }}$ ) a to dle Metodického pokynu. ${ }^{122}$ Ve fázi osobního projednávání je však již nezbytné, aby fyzická osoba, se kterou je řízení vedeno, tedy přihlašovatel, měla také př́stup k utajovaným informacím stejného či vyššího stupně jako je označena přihláška. ${ }^{123} \mathrm{~V}$ tento moment tedy musí proběhnout poučení podle zákona o ochraně utajovaných informací tak, jak bylo uvedeno viz výše. ${ }^{124}$ Následné řízení před Úřadem probíhá standardně dle zákona o vynálezech a prováděcích předpisů s výjimkou zveřejnění vynálezu; ${ }^{125}$ ovšem pro účely

\footnotetext{
${ }^{115}$ Ustanovení čl. 5 odst. 1 Bezpečnostního řádu.

116 Tamtéž čl. 5 odst. 4.

${ }^{117}$ Ustanovení čl. 2 Metodického pokynu.

${ }^{118}$ Ustanovení čl. 6 odst. 5 písm. f) Bezpečnostního řádu.

119 Tamtéž čl. 5 odst. 6.

120 Tamtéž čl. 8 odst. 2.

${ }^{121}$ Ustanovení čl. 2.3 Metodického pokynu.

${ }^{122}$ Ustanovení čl. 8 odst. 3 Bezpečnostního řádu.

${ }^{123}$ Tamtéž čl. 8 odst. 3 .

${ }^{124}$ Ustanovení $\S 70$ odst. 5 patentového zákona.

125 Tamtéž $§ 71$.
} 
úplného průzkumu se utajovaná přihláška považuje za zveřejněnou 18 měsíců od vzniku práva přednosti. ${ }^{126}$ Je tedy proveden standardně předběžný i úplný průzkum a řízení je ukončeno udělením patentu či zamítnutím přihlášky. V každém z těchto případů má pak bezpečnostní ředitel opět povinnost zaznamenat výsledek rízení do databáze. Pokud je patentová ochrana udělena, bezpečnostní ředitel Úřadu zaznamená do databáze i číslo patentového dokumentu a tuto informaci oznamuje ve Věstníku ÚPV. ${ }^{127}$ Vzhledem $\mathrm{k}$ povinnosti nezveřejňovat utajované patentové přihlášky je možné tedy z této úpravy pouze vyvozovat, že se jedná o neveřejnou část Věstníku a nápodobně neveřejnou interní databázi utajovaných patentových přihlášek.

$\mathrm{V}$ př́padě, že bude mít přihlašovatel či majitel za to, že už dále neexistují důvody pro utajování patentu, může požádat o snížení stupně utajení či jeho úplné zrušení u Úřadu, nicméně o žádosti bude rozhodovat Národní bezpečnostní úřad, který rozhodnutí následně oznamuje bezpečnostnímu řediteli a ten pak zpět přihlašovateli či majiteli patentu. ${ }^{128}$

$\mathrm{Na}$ závěr této části bych ráda ještě zmínila $\mathrm{v}$ krátkosti značení utajovaných patentů. Bibliografická data utajovaných vynálezů podléhají stejnému značení, jako u standardního patentu (což nutně vyplývá ze zákonných požadavků, kdy všechny podmínky kromě zveřejnění se aplikují i na utajované přihlášky ${ }^{129}$ ), tuto skutečnost lze, jako jednu z mála v tomto tématu, ověřit prakticky $\mathrm{v}$ online databázi - pro srování lze vyhledat odtajněné patenty a porovnat dokumentaci s patenty standardními. ${ }^{130}$ Nutno ale dodat, že číselné kódy INID pro označování bibliografických dat technických řešení ${ }^{131}$ neobsahují kategorii, která by referovala $\mathrm{k}$ faktu, že přihláška je či byla v minulosti utajovaná. Fakt, že se v minulosti jednalo o utajovanou přihlášku je evidován na naskenovaném patentovém spisu

\footnotetext{
${ }^{126}$ Tamtéž $§ 5$ odst. 3.

${ }^{127}$ Ustanovení čl. 8 odst. 4 Bezpečnostního řádu.

${ }^{128}$ Ustanovení čl. 8 odst. 5 Bezpečnostního řádu. Dle konzultovaných informací se aktuálně jedná v České republice o řádově jednotky návrhů na utajení přihlášek, z nichž je většina zamítnuta. Za poskytnutí této informace děkuji paní JUDr. Evě Maříkové z právního a legislativního odboru Národního bezpečnostního úřadu.

${ }^{129}$ Ustanovení § 71 patentového zákona.
} 
(konkrétně slovy „po odtajněni“) a lze jej vyčíst z INID kategorie číslo 24 referované jako „oznámení o zápisu ve Věstníku (po odtajnění)“. Z tohoto vyjádření v podstatě vyplývá, že udělení utajovaného patentu je ve Věstníku zveřjejněno až jeho odtajněním. Dále lze tuto informaci zjistit z přehledu položek řízení v online databázi, kde se zmiňuje jak žádost o odtajnění (pokud jí bylo vyhověno), ${ }^{132}$ tak i žádost o utajení v případě, že byla zamítnuta. $^{133}$

Ve Věstníku Úřadu je dále použito kódování záhlaví oznámení publikovaných ve Věstníku vyplývající se standardu WIPO číslo $17,{ }^{134}$ které narozdíl od předchozích obsahuje dvě kategorie kódování oznámení, které přímo referují k odtajnění patentů a autorských osvědčení - jedná se o kategorie SB4A a SB4F. ${ }^{135}$ Pomocí těchto kategorií lze ve Věstníku vyhledat odtajněné patenty a autorská osvědčení. ${ }^{136}$

${ }^{130}$ Odtajněné patentové přihlášky a autorská osvědčení např.: SELLIER AND BELLOT A. S. VLAŠIM. Roznětka pro zapalovače. Původce: Václav SVACHOUČEK. Česká republika. Patentový spis CZ 299391 B6. 30. 1. 1997., SELLIER AND BELLOT A. S. VLAŠIM. Zážehová směs. Původce: Jiří NESVEDA, Stanislav BRANDEJS, Radek KOTOUČEK. Česká republika Patentový spis CZ 299392 B6. 13. 8. 1996., SELLIOR AND BELLOT A. S. VLAŠIM. Iniciační slož pro trasovací slož. Původce: Václav SVACHOUČEK. Patentový spis CZ 299393 B6. 21. 12. 1998., MINISTERSTVO OBRANY ČR, ODBOR VĚCNÝCH ZDROJŮ A SPRÁVY ORGANIZACÍ PRAHA. Hydraulická zákluzová brzda s ventilem. Původce: Milan VAŠíČEK, Josef MANĎÁK. Česká republika. Autorské osvědčení CZ 299396 B1. 22. 4. 1986.

${ }^{131}$ WIPO standard st. 9: Recommendation concerning bibliographic data on and relating to patents and SPCS. Handbook on industrial property information and documentation [online]. World intellectual property organization [cit. 28. 2. 2018].

${ }^{132}$ Např.: SELLIER AND BELLOT A. S. VLAŠIM. Roznětka pro zapalovače. Původce: Václav SVACHOUČEK. Česká republika. Patentový spis CZ 299391 B6. 30. 1. 1997.

${ }^{133}$ Přihláška se zamítnutou žádostí na utajení např.: ZVI A. S. PRAHA. Zážehová slož pro elektricky iniciovatelné zápalky. Původci: Václav SVACHOUČEK, Jan KUSÁK, Jiř́̌ STRNAD. Česká republika. Patentový spis CZ 295050 B6. 11. 3. 2005.

${ }^{134}$ WIPO standard st. 17: Recommendation for the coding of headings of announcements made in official gazettes. Handbook on industrial property information and documentation [online]. World intellectual property organization [cit. 28. 2. 2018].

${ }^{135}$ Tamtéž.

${ }^{136} \mathrm{~V}$ online databázi Věstníku vynálezů a patentů Úřadu průmyslového vlastnictví lze aktuálně pod kapitolou „Autorská osvědčení a patenty zapsané do rsjstř̌ku po odtajněni“" nalézt 24 záznamů: Vyhledávání ve Věstníku podle bibliografických údajů [online]. Úřad průmyslového vlastnictví, 2018, [cit. 5. 7. 2018]. 


\subsection{VLASTNICKÁ PRÁVA A LICENCOVÁNÍ}

Tato část práce je zahrnuta $s$ cílem objasnit nakládání $s$ vynálezem po udělení utajovaného patentu. Z praktického hlediska (nebo $\mathrm{z}$ hlediska přihlašovatele a později majitele) se tedy jedná v podstatě o nejdůležitější část problematiky, jelikož se jedná o samotný cíl řízení; udělení patentové ochrany obecně znamená udělení výlučných erga omnes vlastnických práv na nakládání $\mathrm{s}$ vynálezem jeho majiteli, v př́padě utajovaného patentu však lze rozumně předpokládat, že z principu budou tato práva omezena. O to je paradoxnější situace, kde o vlastnických právech a jejich nakládání v případě utajovaného patentu mlčí všechny relevantní výše zmíněné zdroje v kontextu toho, že celá tato práce se potýká s absencí i šǐrí relevantních zdrojů. Jedná se tedy o část tohoto článku, která je založena téměř bezvýhradně na obecných principech pojících se k utajování informací a právům duševního vlastnictví $\mathrm{v}$ kombinaci s konzultacemi s odborníky $\mathrm{v}$ těchto směrech. ${ }^{137}$

Důsledky udělení patentové ochrany na vynález jsou podle zákona o vynálezech zejména majitelovo „výlučné právo využivat nález, poskytnout souhlas $k$ využívání jiným osobám, nebo na ně patent prevézt “" ${ }^{138}$ což je specifikováno dále v následujících paragrafech. ${ }^{139}$ Je patrné, že všechny tyto způsoby nakládání $\mathrm{s}$ vynálezem jsou $\mathrm{v}$ př́padě udělení utajovaného patentu v přímé kontradikci; těžko si lze představit volné využívání majitelem patentu či další osobou pokud je vynález považován za utajovaný, lze tedy legitimně očekávat nějaké omezení majitelových vlastnických práv z důvodu veřejného zájmu.

V tento moment by mohl být nápomocen patentový zákon z dob první republiky č. 305/1919 Sb., ${ }^{140}$ který v podstatě přejímá s drobnými úprava-

\footnotetext{
${ }^{137}$ Autor několika odborných publikací a český i evropský patentový zástupce pan Ing. Karel Čada a paní JUDr. Eva Maříková z právního a legislativního odboru Národního bezpečnostního úřadu.

${ }^{138}$ Ustanovení $\S 11$ odst. 1 patentového zákona.

139 Tamtéž § 13 a § 13a.

140 Zákon č. 305/1919 Sb.
} 
mi rakouský patentový zákon č. 30/1987 ř. z. ${ }^{141}$ Nejprve je nutno říci, že tento zákon vůbec neobsahoval explicitní vyjádření udělení utajovaného patentu jako takového, pouze uváděl, že do rejstříku se zapisují všechny udělené patenty a to včetně těch vyhrazených státu nebo válečné správě, avšak tyto patenty nejsou přístupny $\mathrm{k}$ nahlížení - tedy uveřejněny v pravém slova smyslu. ${ }^{142}$ Naopak ale obsahoval explicitní vyjádření možnosti omezení vlastnických práv $\mathrm{k}$ patentu či úplného vyvlastnění za účelem využití patentu státní nebo válečnou správou (viz níže).

Omezit bylo možné ve prospěch válečné správy, státního monopolu či cizích vozidel na území státu. Omezení ve prospěch cizích vozidel bylo čistě praktickým projevem mezinárodní přepravy, znamená výjimku z patentových práv na vozidla či zařízení na nich, která se na území státu nachází přechodně při použití $\mathrm{k}$ dopravě. ${ }^{143}$ Relevantnější bylo ovšem omezení ve prospěch válečné správy či státního monopolu. Nutno říct, že v tomto ohledu byl patentový zákon poměrně nekompromisní. Jednalo-li se o vynález, který se vztahoval $\mathrm{k}$ „válečným zbraním, třaskavinám, střelivu, opevnění nebo válečným lodím“144 a který by mohl „zvýšit brannou moc“145 státu, měla válečná správa právo využívat vynález a nemohlo být proti ní uplatněno výlučné právo vyplývající z patentu (např. ani nárok na náhradu škody apod.). ${ }^{146}$ Využívání patentu ovšem záviselo na schválení Ministerstvem obchodu, toto rozhodnutí muselo být získáno ještě před začátkem užívání vy nálezu. ${ }^{147}$ Majitel patentu měl právo na přiměřenou náhradu, ta byla stano-

${ }^{141}$ Zákon č. 30/1897 ř. z. Za tuto radu bych na tomto místě ráda poděkovala prof. Karlovi Čadovi.

${ }^{142}$ ŠPIRK, Ludvík; VANĚK, Cyril. Výklad právních předpisů československého práva patentního: výklad zákona ze dne 11. ledna 1897, č. 30 r. z., novelisovaného zákony ze dne 29. prosince 1908, č. 286 r.. z., ze dne 27. května 1919, č. 305 Sb. z. a n., ze dne 30. června 1922, č. 252 Sb. z. a n. a př́slušných nařízení. V Praze: Nákladem vlastním, 1933, s. 63 - 64.

${ }^{143}$ ŠPIRK, Ludvík; VANĚK, Cyril. Výklad právních předpisů československého práva patentního: výklad zákona ze dne 11. ledna 1897, č. 30 r. z., novelisovaného zákony ze dne 29. prosince 1908, č. 286 ř. z., ze dne 27. května 1919, č. 305 Sb. z. a n., ze dne 30. června 1922, č. 252 Sb. z. a n. a př́slušných nařizení. V Praze: Nákladem vlastním, 1933, s. 84.

144 Tamtéž s. 82.

145 Tamtéž.

146 Tamtéž.

147 Tamtéž s. 83. 
vena dohodou mezi majitelem a vojenskou správou, musela být však následně odsouhlasena také Ministerstvem financí. Pokud by však k dohodě nedošlo, tak měl pravomoc rozhodnout o výši náhrady ministr financí s ministrem obchodu a válečnou správu a proti tomuto rozhodnutí není přípustný opravný prostředek. Nutno také dodat, že neukončený proces stanovení výše náhrady nezabraňoval využívání vynálezu vojenskou správou, pokud o tom bylo řádně rozhodnuto v souladu s výše uvedeným. ${ }^{148}$

Omezení patentových práv mohlo nastat i ve prospěch státního monopolu, toto omezení se týkalo předmětů ze zákona vyloučených z patentovatelnosti z důvodu, že byly vyhrazeny státnímu monopolu, které však byly i přesto patentovány (ze zákona by měl být patent po zjištění této skutečnosti na žádost zrušen). Udělení patentu na takovéto předměty pak nemělo účinek vůči státní nebo válečné správě. Jednalo se zejména o „předměty, které jsou používány veřejností, mohou však spadati také pod státní monopol (střelné a trhací látky)“. ${ }^{149}$

Zákon dále obsahoval i institut vyvlastnění patentu, v $§ 15$ byly obsaženy tři způsoby vyvlastnění patentu - vyvlastnění v celém rozsahu, částečně či úplné zrušení patentu za účelem volného užívání veřejností. Důvody k vyvlastnění byly definovány jako „zájem ozbrojené moci nebo veřejného dobra nebo jiný naléhavý zájem státní, aby vynálezu bylo užíáno zcela nebo částečně státní nebo válečnou spárvou samou, anebo aby byl vynález ponechán všeobecnému uživání“. ${ }^{150} \mathrm{~V}$ těchto případech rozdílně oproti omezení vlastnických práv rozhodovalo o žádosti na vyvlastnění Ministerstvo vnitra a to za státní nebo válečnou správu, rozhodnutí pak mělo účinky vůči majiteli i ostatním osobám, které měli užívací práva k vynálezu. Za vyvlastnění příslušela ze zákona přiměřená náhrada všem zmíněným osobám, opět se preferovala dohoda mezi nimi na jedné straně a státní správou na straně druhé, v případě, že $\mathrm{k}$ dohodě nedošlo, tak výši náhrady určil soud na zá-

\footnotetext{
148 Tamtéž.

149 ŠPIRK, Ludvík; VANĚK, Cyril. Výklad právních předpisů československého práva patentního: výklad zákona ze dne 11. ledna 1897, č. 30 r. z., novelisovaného zákony ze dne 29. prosince 1908, č. 286 ř. z., ze dne 27. května 1919, č. 305 Sb. z. a n., ze dne 30. června 1922, č. 252 Sb. z. a n. a př́slušných nařízení. V Praze: Nákladem vlastním, 1933, s. 83 - 84.

150 Tamtéž s. 154 - 155 .
} 
kladě žaloby. Soud přihlížel při vyměřování ke znaleckým posudkům a původní majitel patentu měl právo na to jednoho znalce jmenovat, vždy však přihlížel pouze $\mathrm{k}$ účinkům patentu na státním území. Náhrada měla dvě složky - obecnou tržní cenu a určení pravděpodobných zisků z patentu. Opět zde fungoval princip, že využívání vynálezu státní či válečnou správou (nebo veřejností v některých případech) bylo možné už před rozhodnutím o náhradě škody, dokonce $\mathrm{v}$ některých případech bylo využívání možné již před vydáním vyvlastňovacího nálezu Ministerstvem vnitra, nicméně bylo vyžadováno alespoň svolení Ministerstva s tím, že nález vydá později (zejména hrozilo-li by nebezpečí z prodlení). ${ }^{151} \mathrm{~V}$ případě, že by však Ministerstvo poté $\mathrm{v}$ nálezu vyvlastnění nepovolilo, př́sluší majiteli právo na náhradu škody. ${ }^{152}$ Státní či válečná správa měla poté všechna práva majitele $\mathrm{v}$ rozsahu uvedeném $\mathrm{v}$ nálezu. Tato skutečnost se neuváděla $\mathrm{v}$ rejstř́k $\mathrm{ku}$, pouze ji patentní úřad uvedl $\mathrm{v}$ patentovém spise. ${ }^{153}$ Vyvlastnit bylo možné i práva $\mathrm{k}$ vynálezu, kterému ještě patentová ochrana nebyla udělena a bylo o něm zatím vedeno pouze řízení. ${ }^{154}$

Dle získaných informací však v současné době zákon neumožňuje vyvlastnění ani omezení vlastnických práv ze zákona, všechna vlastnická práva zůstávají majiteli. Za těchto okolností si lze tedy představit pouze smluvně upravené využívání vynálezu státem formou licenční smlouvy dle § 14 patentového zákona.

\subsection{SHRNUTÍ}

V této části byla analyzována právní úprava udílení utajovaných patentů, od úpravy utajovaných informací zvlášt přes definici utajovaného patentu a prameny právní úpravy, který tento institut popisují, až po konkrétní postup řízení, které by mělo vyústit udělením utajovaného patentu. Zaměřila jsem se na ty fáze řízení, které se odlišují od běžného řízení o udělení patentu a jejich rozbor. $\mathrm{V}$ poslední části jsem nejvíce narazila na absenci re-

\footnotetext{
${ }^{151}$ Tamtéž s. 155.

152 Tamtéž, s. 156.

153 Tamtéž s. 155 - 156.

154 Tamtéž s. 156.
} 
levantních zdrojů a je tudíž vypracována pouze na základě obecných principů, prríkladu historické právní úpravy a odborné konzultace, otevírá ovšem prostor pro další výzkum.

\section{UTAJOVANÝ PATENT VE VYBRANÝCH PRÁVNÍCH SYSTÉMECH A KOMPARACE S ČESKOU PRÁVNÍ ÚPRAVOU}

Druhá část tohoto článku má za cíl porovnat právní úpravu utajovaných patentů v České republice s jejich právní úpravou ve Spojených státech, Spojeném království a Německu. Ačkoliv se jedná o státy s právními systémy více či méně vzdálenými, jejich výběr byl účelový vzhledem k tomu, že se jedná o státy, které tohoto institutu využívají mnohem více, což se odráží i v mnohem konkrétnější právní úpravě. ${ }^{155}$ Tento př́ispěvek však nemá ambice porovnat celé fungování utajovaného patentu v těchto zemích $\mathrm{s}$ tuzemskou úpravou tak, jak bylo popsáno výše; jednalo by se o cíl hodný minimálně ještě jednou stejného rozsahu, jako je tento článek. Spíše se zaměřím na průběh řízení o utajované patentové přihlášce a dále porovnání vlivu udělení utajovaného patentu na vlastnická práva vynálezce. Zkoumaná otázka je pojata poměrně široce $\mathrm{z}$ důvodu, že je obtížné získat relevantní a důvěryhodné informace o všech třech dílčích podotázkách ze všech zkoumaných právních systémů, současně si ale myslím, že každá z nich je př́liš důležitá pro dokreslení celkového obrazu fungování utajovaných patentů na to, aby nebyla zahrnuta vůbec.

Postupovat budu podle komparativní metody práva. ${ }^{156}$ Zkoumaná otázka je tedy, jak je právně upraven utajovaný patent ve srovnávaných právních řádech a jaký vliv má udělení utajovaného patentu na vlastnická práva majitele. ${ }^{157}$ Tato otázka souvisí úzce zejména se základním právem na ochranu soukromého vlastnictví, s právem na informace, principem veřejnosti pa-

\footnotetext{
${ }^{155}$ Total Secrecy Orders in effect (at end of period). Invention Secrecy Activity (as reported by The Patent and Trademark Office) [online]. Federation of American Scientists, (c) 2018 [cit. 15. 3. 2018]. Official Statistics. Facts and figures: patent, trade mark, design and hearing data: 2016 - GOV.UK [online]. (C) Crown Copyright, publikováno 2. 11. 2017 [cit. 15. 3. 2018].

${ }^{156}$ SAMUEL, Geoffrey. An introduction to comparative law theory and method. Portland, Oregon: Hart Publishing, 2014. s. 26.

${ }^{157}$ Tamtéź.
} 
tentového práva tak, jak byl analyzován výše a transparentním fungováním státní správy. Tertium comparationis bude $\mathrm{v}$ tomto případě právní úprava utajovaného patentu ve všech právních řádech, a to zejména ta část, ve které je rozhodováno o přihlášce - zda-li obsahuje utajované informace a udělen tedy bude utajovaný patent či nikoliv a to z důvodu, že se jedná o klíčové rozhodnutí, které již nelze zvrátit ( $v$ některých případech sice lze, ale jen s obtížemi, jak bude uvedeno viz níže) a o případném omezení vlastnických práv. Comparatum bude tedy tuzemská právní úprava související s rozhodnutím o utajení patentové přihlášky, zejména tedy čl. 7 a 8 Bezpečnostního řádu Úřadu průmyslového vlastnictví, comparandum ${ }^{158}$ pak bude v právním řádu Spojených států $§ 181$ a násl. amerického patentového zákona ${ }^{159}$ a v právním řádu Spojeného království v části 22 a 23 patentového zákona $\mathrm{z}$ roku $1977^{160}$ a $\mathrm{v}$ německém patentovém zákoně $\S 50$ a násl. ${ }^{161}$

\section{1 ČESKÁ PRÁVNÍ ÚPRAVA}

Tímto tématem jsem se $\mathrm{v}$ podstatě zabývala $\mathrm{v}$ první části tohoto článku, ovšem pro účely srovnání se domnívám, že by se hodilo krátké shrnutí vzhledem $\mathrm{k}$ tomu, že se jedná o comparatum. V českém právním systému je utajovaná patentová přihláška řešena velmi stručně na zákonné úrovni (jedná se pouze o pár zmínek v zákoně o vynálezech ${ }^{162}$ a jeden paragraf zákona o utajovaných informacích ${ }^{163}$ ), konkrétnější podmínky stanovují prováděcí předpisy výkonných orgánů na poli národní bezpečnosti a prů-

\footnotetext{
${ }^{158}$ Viz ÖRÜCÜ, A. Esin. Methodology of comparative law. In: SMITS, Jan M. Elgar Encyklopedia of Comparative Law. 1 ed. Cheltenham: Edward Elgar Publishing Limited, 2006, s. 442.

159 SPOJENÉ STÁTY. § 181 et seq. Invention Secrecy Act of 1951, Title 35 of United States Code, Pub. L. 82-256 (dále jen „35 U.S.C.“).

${ }^{160}$ SPOJENÉ KRÁLOVSTVÍ. Sec. 22 - 23. Patents Act of 1977, Chapter 37 (dále jen „Patents Act").

${ }^{161}$ NĚMECKO. § 50 - § 56 Patengesets vom 16. Dezember 1980, BGBl. 1981 I S. 1 (dále jen „PatG").

162 Konkrétně § 4, § 24 a $§ 71$ patentového zákona.

163 Konkrétně $§ 71$ zákona o ochraně utajovaných informací.
} 
myslového vlastnictví - tedy vyhlášky Národního bezpečnostního úřadu ${ }^{164}$ a Úřadu průmyslového vlastnictví. ${ }^{165}$ Hlavní odpovědnost za detekci utajovaných informací má dle Bezpečnostního řádu přihlašovatel - on je ten, kdo navrhuje stupeň utajení. ${ }^{166} \mathrm{~V}$ případě, že by utajení nebylo navrhnuto přihlašovatelem je možné, aby jej navrhnul ještě také zaměstnanec Úřadu během řízení o přihlášce. ${ }^{167} \mathrm{O}$ stupni utajení poté rozhoduje Národní bezpečnostní úřad na základě vyžádaných posudků (viz výše). ${ }^{168} \mathrm{~V}$ praxi se nejčastěji jedná právě o ty případy, kdy je stupeň utajení navrhnut přihlašovatelem a následně je zamítnut Národním bezpečnostním úřadem. ${ }^{169}$ Nakládání s vynálezem po udělení utajovaného patentu vzhledem $\mathrm{k}$ výše uvedenému nejspíše probíhá formouvzájemné dohody (pravděpodobně licenční smlouvy) mezi majitelem a státem.

\subsection{PRÁVNÍ ÚPRAVA VE SPOJENÝCH STÁTECH}

Porovnávanou problematiku upravuje v právním řádu Spojených států zejména $\S 181$ a násl. zákona č. 35/1951 („,35 U.S.C.). ${ }^{170}$ Toto ustanovení má několik specifik. Prvním je zejména to, že americký právní systém rozlišuje mezi přihlášením vynálezu, který byl financován částečně či zcela státem nebo některou jeho organizační složkou a čistě soukromým vynálezem. ${ }^{171}$ Toto rozlišení je pro účel komparace důležité zejména proto, že vynálezy financované státem je samozřejmě jednodušší utajit v rámci patentového řízení než ty soukromé. Druhým specifikem je to, že v případě rozhodnutí o utajení není patent vůbec udělen.

V právním systému Spojených států existuje poměrně podrobný soubor pravidel týkajících se utajovaného patentu již na zákonné úrovni, ve výše

\footnotetext{
${ }^{164}$ Např. vyhláška o administrativní bezpečnosti.

165 Např. Bezpečnostní řád či Metodický pokyn.

${ }^{166}$ Ustanovení čl. 7 odst. 1 Bezpečnostního řádu.

167 Tamtéž čl. 8 odst. 6.

168 Tamtéž čl. 8 odst. 1.

${ }^{169}$ Za poskytnutí této informace děkuji paní JUDr. Evě Maříkové.

${ }^{170}$ SPOJENÉ STÁTY. Ustanovení § 181 až § 18835 U.S.C.

${ }^{171}$ Tamtéž § 181.
} 
zmíněném zákoně. ${ }^{172}$ Ta obsahují konkrétní popis detekce utajovaných vynálezů, orgány vstupující do řízení o udělení, náhradu škody či pokutu při neuposlechnutí př́kazů vyplývajících $\mathrm{z}$ tohoto zákona. ${ }^{173}$ Základním pravidlem je to, že americký Úřad patentů a ochranných známek („The United States Patent and Trademark Office") prochází všechny patentové přihlášky, které jsou mu doručeny, k tomu využívá tzv. průvodce orgánů obrany, které poskytují vodítka $\mathrm{k}$ určení, zda se jedná o informaci, jejíž zveřejnění může být škodlivé pro národní bezpečnost. ${ }^{174}$ Výjimkou jsou pouze přihlášky na vynálezy, které jsou částečně či úplně vlastněny státem (tzv. vládní přihlášky) $-\mathrm{v}$ těchto případech je povinností přihlašovatele (tedy státní organizace), aby procházel svoje přihlášky a př́ípadně navrhnul utajení Úřadu patentů a ochranných známek sám. ${ }^{175}$ Pakliže by soukromá patentová přihláška mohla obsahovat informace, jejichž zveřejnění by mohlo poškodit národní bezpečnost, patentový komisař pak zpřístupní takovou přihlášku Ministerstvu obrany a to skrze jeho poradní výbor pro patenty ozbrojených služeb. Ministerstvo obrany či nějaká $\mathrm{z}$ jeho složek pak zkoumá důvodnost utajení této přihlášky. Jestliže dojde $\mathrm{k}$ závěru, že by informace $\mathrm{v}$ přihlášce neměly být zveřejněny, doporučí tento závěr zpět poradnímu výboru, který poté doporučí patentovému komisaři vydat př́ikaz k utajení přihlášky. ${ }^{176}$ Vedle této linie existuje paralelně řízení pod Ministerstvem energie, které má také pravomoc procházet všechny doručené přihlášky za účelem detekovat ty, které souvisejí s jadernou energií a souhlasně doporučit patentovému komisaři vydání př́kazu $\mathrm{k}$ utajení přihlášky. Proti př́íkazu $\mathrm{k}$ utajení je možné podat opravný prostředek. ${ }^{177}$

\footnotetext{
172 SPOJENÉ STÁTY. Ustanovení § 122, § 133, § 151, § 181 až § 18835 U.S.C.

${ }^{173}$ Tamtéž $\S 181$ až $\S 188$.

${ }^{174}$ ARMER SERVICES PATENT ADVISORY BOARD. Patent Security Category Review List [online]. Federation of American Scientists, (C) 2018 [cit. 15. 3. 2018].

175 The Secrecy Order Program in the United States Patent \& Trademark Office. Federation of American Scientists, (C) 2018 [cit. 15. 3. 2018].

${ }^{176}$ Tamtéž. Existují dokonce tři druhy těchto př́ikazů, jejich rozlišení však není pro účely této komparace podstatné.

177 CITRIN, Adam J. Are the Secrecy Order Compensation Provisions of the Patent Act Constitutional Under the Fifth Amendment? 2007, vol. 1, s. 279.
} 
$\mathrm{V}$ případě, že je vydán příkaz $\mathrm{k}$ utajení přihlášky pak není patent udělen, přestože řízení dojde až do momentu, kdy by udělen za standardních okolností byl. Ten je udělen až v moment odtajnění ( $\mathrm{v}$ těchto případech pak může být rozdíl mezi datem podání přihlášky a udělením patentu i několik desítek let, viz patentová přihláška v poznámce pod čarou ${ }^{178}$ ). Dále podle typu př́kazu $\mathrm{k}$ utajení je mu zakázáno přihlásit vynález v cizí zemi anebo i podáním mezinárodní či evropské přihlášky (u některého typu to od uzavření Dohody o vzájemném zabezpečení utajení vynálezů možné je, nicméně pouze se souhlasem patentového komisaře) a dále jej nelze licencovat na volném trhu (což je nutným důsledkem zákazu jakéhokoliv zveřenění patentu). ${ }^{179}$ Sankcí za odtajnění či přihlášení vynálezu mezinárodní přihláškou či standardní cestou v zahraničí je pak pokuta do výše 10000 dolarů, až dva roky odnětí svobody anebo kombinace těchto trestů. ${ }^{100}$ Jako satisfakci za omezení těchto vlastnických práv $\mathrm{k}$ vynálezu má však vynález${ } e^{181}$ právo na náhradu ušlého zisku i za využívání jeho vynálezu státem. ${ }^{182}$ K získání finanční satisfakce musí podat žádost k tomu státnímu orgánu, který „prakticky“ rozhodl o utajení - tedy tomu, který projevil zájem o využívání přihlašovaného vynálezu - a to do šesti let od vydání utajovacího př́kazu. ${ }^{183}$ Prioritu má ze zákona dohoda mezi daným státním orgánem a vynálezcem o výši finanční náhrady ${ }^{184}$, pokud takové dohody zúčastnéně

\footnotetext{
${ }^{178} \mathrm{~V}$ odkazu viz níže uvádím př́ikad odtajněné patentové přihlášky, které byl patent udělen až necelých 15 let po přihlášení. (THE CHARLES STARK DRAPER LABORATORY, INC. Fused PM fiber single-polarisation resonator. United States of America. US 9115993 B1. 30. 8. 1990.) V USA je dále znám př́pad opravdu dlouhé doby utajení vynálezu, který byl řešen u soudu: Rozsudek Okresního soudu v Massachusetts ve věci Stein v. United States ze dne 6. dubna 2001, sp. zn. [135 F. Supp. 2d 265], kde byl př́íkaz k utajení v platnosti od 9. dubna 1873 do 33. března 2000.

${ }^{179}$ CITRIN, Adam J. Are the Secrecy Order Compensation Provisions of the Patent Act Constitutional Under the Fifth Amendment? 2007, vol. 1, s. 275 - 276.

${ }^{180}$ SPOJENÉ STÁTY. Ustanovení § 18635 U.S.C.

${ }^{181}$ Termín „vynálezce“ je užit vzhledem k matoucí terminologii - nejedná se totiž ještě o majitele, jelikož patent není udělen, nicméně je ve stavu, jakoby udělen byl (příkaz k utajení je „udělen" místo patentu). I nadále bude užíváno spíše tohoto termínu než-li duálních termínu přihlašovatel a majitel, které by mohly být vzhledem $\mathrm{k}$ dané situaci nepřesné.

${ }^{182}$ SPOJENÉ STÁTY. Ustanovení § 18335 U.S.C.

${ }^{183}$ Tamtéž.

${ }^{184}$ SPOJENÉ STÁTY. Ustanovení § 18335 U.S.C.
} 
strany nedojdou, je způsob získání konkrétní částky dán zákonem, ačkoliv je toto ustanovení definováno poměrně vágně. ${ }^{185}$ Částku pak určuje vedoucí daného státního orgánu a nesmí přesahovat 75 procent částky, kterou tato strana považuje za přiměřenou kompenzaci ušlého zisku a užívání vynále$\mathrm{zu} ;{ }^{186}$ zákon pak ale nespecifikuje, jak se určuje přiměřená částka a ani moment, kdy lze konstatovat, že dohody nelze dojít.

Na závěr této analýzy bych uvedla některé statistiky z utajování vynálezů v USA pro představu jak často je tento institut využíván a případné porovnání s dalšími získanými daty. Za fiskální rok 2017 bylo evidováno 5 784 příkazů $\mathrm{k}$ utajení $\mathrm{v}$ účinnosti (znamená to, že toto číslo může zahrnovat mimo vynálezy i průmyslové vzory apod.), ${ }^{187}$ vedle 347243 udělených patentů celkově (opět včetně průmyslových vzorů atd.) ${ }^{188}$ bylo utajovacích př́kazů vydáno $132,{ }^{189}$ což je asi $0,04 \%$, z toho 39 jich bylo vydáno na čistě soukromé vynálezy, zbylé byly spolufinancovány státem, a dále bylo 28 vynálezů odtajněno. ${ }^{190}$ Vzhledem k minulým letům je spíše klesající trend poměrů utajovaných příkazů na udělené patenty - mezitím co patentových přihlášek přibývá, utajovacích př́kazů ubývá. ${ }^{191}$

\subsection{PRÁVNÍ ÚPRAVA VE SPOJENÉM KRÁLOVSTVÍ}

Právní úprava ochrany utajovaných vynálezů ve Spojeném království vychází z patentového zákona č. 37 z roku 1977 („Patents Act 1977“), jedná

185 Tamtéž.

186 Tamtéž.

${ }^{187}$ Total Secrecy Orders in effect (at end of period). Invention Secrecy Activity (as reported by The Patent and Trademark Office) [online]. Federation of American Scientists, (c) 2018 [cit. 15. 3. 2018].

188 TABLE 1: Summary of Patent Examining Activities (FY 2013 - FY 2017). United States Patent and Trademark Office: Performance and Accountability Report FY 17 [online]. United States Patent and Trademark Office, 2017, s. 172 [cit. 15. 3. 2018].

189 Total Secrecy Orders in effect (at end of period). Invention Secrecy Activity (as reported by The Patent and Trademark Office) [online]. Federation of American Scientists, (C) 2018 [cit. 15. 3. 2018].

190 Tamtéž.

191 TABLE 1: Summary of Patent Examining Activities (FY 2013 - FY 2017). United States Patent and Trademark Office: Performance and Accountability Report FY 17 [online]. United States Patent and Trademark Office, 2017, s. 172 [cit. 15. 3. 2018]. 
se konkrétně o články 22 a $23 .{ }^{192} \mathrm{~V}$ některých nosných bodech je úprava podobná patentovému zákona USA, zejména co se týče neudělení patentové ochrany vůbec $\mathrm{v}$ př́padě, že by podle státní správy měl být vynález utajen. Potencionálně utajovaná přihláška je definována jako taková, která obsahuje informace, jejichž zveřejnění by mohlo ohrozit národní nebo veřejnou bezpečnost. ${ }^{193}$ Úřad duševního vlastnictví Spojeného království („The Intellectual Property Office“) vydal k tomuto účelu seznam technologických oblastí, ve kterých je pravděpodobné, že by přihlašovaný vynález mohl podléhat utajení podle zákona. ${ }^{194}$ Stejně jako v př́ípadě Spojených států, i zde jsou úplně všechny přihlašované vynálezy kontrolovány, zda neobsahují utajovanou informaci. ${ }^{195} \mathrm{~V}$ př́padě, že kontrolor usoudí, že by přihlǎška takovou informaci obsahovat mohla, vydá příkaz k utajení. ${ }^{196} \mathrm{Již} \mathrm{od}$ toho momentu jsou značně omezena práva vynálezce nakládat $s$ vynálezem - nesmí jej zveřejňovat ani podat mezinárodní nebo evropskou přihlášku anebo jej přihlásit v jiném státě, ${ }^{197}$ navíc patent nesmí být vůbec udělen. ${ }^{198}$ Přihlášku dále zkoumá státní tajemník, který rozhoduje o tom, zda byl př́íkaz důvodný - v př́ípadě, že usoudí, že důvodný byl, je příkaz nadále platným, nicméně musí být tajemníkem dále pravidelně přezkoumáván. ${ }^{199}$ $\mathrm{V}$ případě, že rozhodne, že utajení není důvodné, informuje o tomto rozhodnutí kontrolora, který př́ikaz $\mathrm{k}$ utajení zruší a patent může být udělen. ${ }^{200}$ Proti př́íkazu $\mathrm{k}$ utajení je dále také možný opravný prostředek, který se podává na Ministerstvo obrany a požaduje zrušení př́íkazu $\mathrm{k}$ utajení. ${ }^{201}$

\footnotetext{
${ }^{192}$ SPOJENÉ KRÁLOVSTVÍ. Sec. 22 - 23 Patents Act.

${ }^{193}$ Tamtéž sec. 22 (1) a (2).

${ }^{194}$ Technology which may be subject to section 22 of The Patents Act. Technology prejudicial to national security or public safety - GOV.UK [online]. (c) Crown Copyright, publikováno 25. 2. 2008 [cit. 15. 3. 2018].

${ }^{195}$ Guidance. National security checks on patent applications - GOV.UK [online]. (C) Crown Copyright, publikováno 9. 4. 2014 [cit. 15. 3. 2018].

${ }^{196}$ SPOJENÉ KRÁLOVSTVÍ. Sec. 22 (1) a (2) Patents Act.

${ }^{197}$ Tamtéž sec. 23 (1).

${ }^{198}$ SPOJENÉ KRÁLOVSTVÍ. Sec. 22 (3) Patents Act.

${ }^{199}$ Tamtéž sec. 22 (5) písm. a), b) a c).

${ }^{200}$ Tamtéž sec. 22 (5) písm. d) a e).

${ }^{201}$ Guidance. National security checks on patent applications - GOV.UK [online]. (C) Crown Copyright, publikováno 9. 4. 2014 [cit. 15. 3. 2018].
} 
V případě porušení některého z uvedených příkazů hrozí vynálezci, či jiné osobě, sankce nejvýše 1000 liber nebo až dva roky odnětí svobody, případně kombinace. ${ }^{202}$ Vynálezci pak opět př́ísluší obecná finanční náhrada podle čl. 57A patentového zákona, což je náhrada ušlého zisku spolu s náhradou nedostatečného využití potenciálu vynálezu, kterou v případě, že se vynálezce se státním orgánem odpovědným za využívání vynálezu nedohodne, určuje soud. ${ }^{203}$ Vedle toho lze ještě žádat náhradu podle čl. 22 odst. 7 patentového zákona, kterou lze získat za prokázané těžkosti, které vznikly vynálezci v souvislosti s utajením vynálezu. ${ }^{204}$

Co se týče statistických hodnot, k datu odevzdání této práce byla uveřejněna pouze data za rok 2016. Na konci roku 2016 bylo pod prŕíkazem k utajení 104 patentových přihlášek. Během roku bylo patentových přihlášek odtajněno 10 a přihlášeno celkem 53 nových (a co je zajímavé, to včetně 6 zahraničních), z toho 46 přihlašovatelů bylo veřejných, a 51 zůstalo účinných $\mathrm{z}$ předchozího roku. ${ }^{205}$ Celkově bylo přitom uděleno v tomto roce 2893 patentů, což znamená že těch utajených z nich bylo asi 1,8\%.

\subsection{PRÁVNÍ ÚPRAVA V NĚMECKU}

Německá úprava detekování a právní ochrany utajovaných vynálezů je pak už blíže té naší, a to mimo jiné v tom, že i v Německu neexistuje veřejně př́stupná statistika utajovaných vynálezů tak, jak byla zmíněna výše u Spojených států amerických a Spojeného království. Narozdíl od české právní úpravy je však v té německé utajování vynálezů jasně definováno na úrovni zákona. $^{206}$

Utajovaná přihláška je definována jako přihláška na vynález, který je státním tajemstvím, ${ }^{207}$ státní tajemství je definováno v německém trestním

\footnotetext{
${ }^{202}$ SPOJENÉ KRÁLOVSTVÍ. Sec. 22 (9) Patents Act.

${ }^{203}$ Tamtéž sec. 57A (3) a (5).

${ }^{204}$ Tamtéž sec. 22 (7).

${ }^{205}$ Official Statistics. Facts and figures: patent, trade mark, design and hearing data: 2016 GOV.UK [online]. (C) Crown Copyright, publikováno 2. 11. 2017 [cit. 15. 3. 2018].

${ }^{206}$ NĚMECKO. § 50 - § 56 PatG.

${ }^{207}$ Tamtéž $\S 50$ odst. 1.
} 
zákoníku. ${ }^{208}$ Proces je také velmi podobný tomu českému. Přezkumné oddělení Patentového úřadu („Deutsches Patent und Markenamt“) zkoumá při doručení všechny patentové přihlášky, zda jejich obsah nepředstavuje státní tajemství. $\mathrm{V}$ případě, že by státní tajemství přihláška obsahovat mohla, pak přezkumné oddělení přihlášku konzultuje s př́slušným oddělením federální vlády (např. Ministerstvo obrany). ${ }^{209}$ Dle výsledku konzultace pak vydá případně př́kaz, podle kterého nesmí být obsah takové přihlášky uveřejněn. ${ }^{210}$ Řízení o udělení patentové ochrany pak probíhá jako u standardního patentu s výjimkou povinnosti zveřejnění přihlášky; pokud přihláška splňuje zákonné náležitosti, je na závěr řízení patent udělen. ${ }^{211}$ Takový vynález se poté považuje, stejně jako v tuzemské právní úpravě, za součást dosavadního stavu techniky po uplynutí lhůty 18 měsíců od data podání přihlášky ${ }^{212}$ a zapisuje se do speciálního rejstř́íku. ${ }^{213}$ Přezkumné oddělení úřadu má dále povinnost zkoumat důvodnost utajování vynálezů $\mathrm{v}$ zákonných lhůtách jednoho roku. ${ }^{214}$ Proti rozhodnutí o utajení či neutajení přihlášky je možný opravný prostředek. ${ }^{215}$ Dále zákon požaduje souhlas př́islušného oddělení federální vlády $\mathrm{k}$ přihlášení utajované přihlášky do zahraničí, či mezinárodní nebo evropské přihlášky, pod hrozbou sankce až pěti let odnětí svobody a pokutou nespecifikované výše. ${ }^{216}$

Tento zákon podobně jako tuzemská úprava zmiňuje zákaz zveřejňování a dále omezené možnosti přihlašovat vynález do zahraničí, je tedy nutné vycházet také z obecných principů a úpravy. Vzhledem $\mathrm{k}$ tomu, že patent je fakticky udělen, má jeho majitel všechna vlastnická práva dle obecné

\footnotetext{
${ }^{208}$ NĚMECKO. § 93 Strafgesetzbuch vom 13. November 1998, BGBl. I S. 3322 (§ 93 německého trestního zákoníku).

${ }^{209}$ NĚMECKO. § 56 PatG.

${ }^{210}$ Tamtéž $§ 50$ odst. 1 .

${ }^{211}$ FITZNER, Uwe et al. Beck'scher Online-Kommentar Patentrecht. § 54 [Besonderes register für Geheimpatente]. 4. ed. München: C. H. Beck, 2017.

${ }^{212}$ FITZNER, Uwe et al. Beck'scher Online-Kommentar Patentrecht. § 54 [Besonderes register für Geheimpatente]. 4. ed. München: C. H. Beck, 2017.

${ }^{213}$ Tamtéž.

${ }^{214}$ Tamtéž $§ 50$ odst. 2.

${ }^{215}$ Tamtéž § 73.

${ }^{216}$ Tamtéž $§ 52$.
} 
úpravy podle komentáře $\mathrm{k}$ patentovému zákonu. ${ }^{217}$ Pakliže by však chtěl svoje práva uplatnit u soudu, jednalo by se o řízení s vyloučením veřejnosti. Dále je nutno zmínit, že k využívání vynálezu či jeho licencování je nutné přijmout dostatečná ochranná opatření, aby nedošlo k uveřejnění technologie, porušení této povinnosti může být trestným činem proti zachování mlčenlivosti. ${ }^{218}$ Právo na náhradu naopak explicitně zmíněno v zákoně je, majitel se ho může domáhat $v$ př́ípadě, že nemůže využívat svůj vynález $\mathrm{z}$ důvodu uděleného příkazu $\mathrm{k}$ utajení. Výsledná částka zohledňuje několik faktorů - výši výdajů vynaložených na vznik vynálezu, nemožnost nakládání s vynálezem apod. ${ }^{219}$

\subsection{KOMPARACE}

V této části bych ráda shrnula a porovnala výše zjištěné poznatky o právní úpravě zkoumaných aspektů utajovaných patentů. Komparaci rozdělím na tři tématické části dle podotázek zkoumané otázky - řízení, vlastnická práva a náhrada a statistiky.

Z historického, společenského i ekonomického vývoje vybraných států lze zpozorovat dva odlišné přístupy $\mathrm{k}$ problematice řízení. Spojené státy americké a Spojené království disponují úpravou, která vůbec patent neudělí, dokud je považován za utajovaný, mezitím co právní úprava v Německu a v České republice patent standardně uděluje, pouze jej nezveřejňuje. V tomto ohledu je z pohledu ochrany soukromého vlastnictví prvně zmiňovaný způsob mnohem invazivnější, vynálezce je po celou dobu pouze v postavení přihlašovatele a nemůže tedy vůbec využívat práva přiznaná majiteli patentu. Může lehce nastat situace, kdy v momentě odtajnění vynálezu patent nebude udělen vůbec, jelikož již nebude splňovat někerou $\mathrm{z}$ podmínek patentovatelnosti (např. novost) - v případě, že je rozhodnuto o odtajnění vynálezu, může to mimo jiné znamenat, že už se nejedná o toliko novou technologii, jejíž zveřejnění by mohlo poskytnout jiným státům

\footnotetext{
${ }^{217}$ FITZNER, Uwe et al. Beck'scher Online-Kommentar Patentrecht. § 54 [Besonderes register für Geheimpatente]. 4. ed. München: C. H. Beck, 2017.

${ }^{218}$ Tamtéž.

${ }^{219}$ NĚMECKO. § 55 PatG.
} 
např. konkurenční výhodu, těžko tedy předpokládat, že bude patent opravdu udělen. Ve všech srovnávaných státech kromě České republiky je úprava utajované patentové přihlášky a nakládání s ní upravena explicitně zákonnými ustanoveními, s tím, že je tato úprava konkretizována nařízeními patentových úřadů apod. V České republice však celé řízení upravuje v podstatě v konkrétní formě alespoň Bezpečnostní řád, nicméně jedná se o právní pramen podzákonné síly, který vydává předseda ÚPV a jeho změny nepodléhají rozhodně takové veřejné kontrole a přísným procesním pravidlům jako je legislativní proces, spíše naopak. Vlastnická práva a jejich omezení nejsou nakonec konkrétně upravena na žádné úrovni. Zákonné omezení vlastnických práv lze subsidiárně dovodit ze zákona o ochraně utajovaných informací, nicméně úprava náhrady za utajení vynálezu chybí úplně. Domnívám se, že se nejedná o legální přístup vzhledem $\mathrm{k}$ tomu, že utajení přihlášky může mít dopady na vlastnická práva $\mathrm{k}$ duševnímu vlastnictví, což je základní právo chráněné Listinou základních práv a svobod, z jejiž dikce vyplývá, že vlastnické právo lze obecně omezit pouze na základě zákona a za náhradu. ${ }^{220}$

Čímž jsem se dostala ke druhé zkoumané podotázce - vlivu utajení přihlášky na vlastnická práva. Lze konstatovat, že česká právní úprava je $\mathrm{v}$ tomto ohledu nejméně konkrétní a obsáhlá. Na zákonné úrovni neobsahuje pravidla žádná. Nutno říct, že v tomto ohledu ani ostatní úpravy nebyly vyloženě konkrétní. Všechny obsahovaly podobný zákaz zveřejňování a zákaz přihlašování do zahraničí pod hrozbou sankce, nicméně konkrétní nakládání s vynálezem po utajení ani jedna nespecifikovala. Zásadním rozdílem je však to, že v právním systému Spojených států a Spojeného království patent není udělen vůbec a nelze tudíž přímo mluvit o vlastnických právech plynoucích z ochrany a o jejich omezení. Podle německého a českého patentového zákona pak patent udělen je a majiteli svědčí veškerá práva plynoucí z jeho ochrany až na omezení uvedená explicitně $\mathrm{v}$ zákoně (např́íklad zákaz zveřejnění).

\footnotetext{
${ }^{220}$ Ustanovení čl. 11 Usnesení České národní rady č. 2/1993 Sb., o vyhlášení Listiny základních práv a svobod, ve znění pozdějších předpisů.
} 
Podobně problematická je v některých státech i úprava určení výše náhrady vynálezci; v USA ji dokonce někteří pokládají za protiústavní, ${ }^{221}$ protože je definována vágními pojmy a určována v případě vzájemného nedohodnutí jednostranně daným úřadem, podobně to překvapivě upravuje i německý patentový zákon. O něco „spravedlivější“ je potom úprava Spojeného království, kde výši určuje soud, nese to sebou tedy i všechny zákonné opravné prostředky atd., navíc je takové řešení určitě více v souladu s principem právní jistoty a legitimního očekávání. Opět se budu opakovat konstatováním, že v tuzemské právní úpravě toto téma vůbec nezaznívá. $Z$ výše uvedeného však lze předpokládat, že v rámci české právní úpravy probíhá využívání utajovaného vynálezu státem na základě vzájemné dohody (pravděpodobně v podobě licenční smlouvy). Vzhledem k tomu, že vynález nemůže být majitelem uveden na trh, je vyjednávací pozice této strany do značné míry omezená.

Co se týče statistických dat, tak jsou veřejně dostupná pouze ta z USA a Spojeného království, což je dle mého názoru také jistý ukazatel transparentnosti veřejné správy. Myslím, že největší informační hodnotu má srovnání percentuelního zastoupení utajovaných přihlášek ze všech udělených patentů v platnosti za dané období, což je $0,04 \%$ v USA a 1,8\% ve Spojeném království ( $\mathrm{v}$ Německu a v České republice tyto údaje volně dostupné nejsou). Pouze $\mathrm{z}$ dílčích informací z odborné konzultace víme, že v České republice se jedná řádově o jednotky utajovaných patentů (viz výše), což je vzhledem k údaji 5985 udělených národních patentů asi pouhých $0,16 \%{ }^{222}$ Jedná se však o absolutní čísla - tedy poměr celkově utajovaných přihlášek s cekovým počtem zapsaných aktivních patenti̊. Údaje z posledního roku tak, jak jsou porovnávány v USA a Spojeném království, se získat nepodařilo.

V této části byly porovnány čtyři různé právní úpravy utajované patentové přihlášky z hlediska přihlašování a následného nakládání s touto při-

${ }^{221}$ CITRIN, Adam J. Are the Secrecy Order Compensation Provisions of the Patent Act Constitutional Under the Fifth Amendment? 2007, vol. 1, s. 275 - 276.

${ }^{222}$ Národní patenty a validované evropské patenty platné na území České republiky k 31. 12. 2017, Výroční zpráva Úřadu průmyslového vlastnictví České republiky 2017. [online]. Úřad průmyslového vlastnictví, 2018, [cit. 20. 6. 2018]. 
hláškou. Všechny úpravy měly některé základní společné rysy co se týče detekce utajovaných informací v přihláškách, příkazů $\mathrm{k}$ utajení a následného řízení, větší rozdíly pak spatřuji zejména $\mathrm{v}$ nakládání s přihláškou po jejím utajení. V USA a Spojeném království nebyl patent vůbec udělen narozdíl od tuzemské a německé právní úpravy, naproti tomu však tyto dvě země pravidelně zveřejňují statistiky utajování vynálezů. Z porovnání však jednoznačně vyplynulo, že právě česká úprava je nejméně obsáhlá a konkrétní, některé věci dokonce nejsou upravené vůbec, avšak současně je zde tohoto institutu pravděpodobně nejméně využíváno.

\section{SHRNUTÍ A ÚVAHA DE LEGE FERENDA}

Tato poslední část práce shrnuje poznatky z částí předchozích a na jejich základě by měla nabídnout úvahu, jakým způsobem lze tuzemskou právní úpravu posouvat $\mathrm{k}$ optimálnějšímu stavu.

Jak již bylo několikrát uvedeno, problémem je nedostatečná a roztříštěná právní úprava tohoto typu patentů na zákonné úrovni - jedná se jen o několik dílčích zmínek. Původ tohoto problému může souviset se statistickými daty, která hovoří tak, že tohoto institutu je využíváno tak málo, že není potřeba pro ně vyžadovat separátní úpravu. Já mám nicméně za to, že i přesto by takováto problematika měla být řešena zákonnou úpravou. Domnívám se, že nedosažení většího počtu přihlášení utajovaných patentů není důvodem, proč neupravit precizněji související otázky.

Jediná právní úprava řízení o udělení utajovaného patentu tak jak je popsána v Bezpečnostním řádu Úřadu průmyslového vlastnictví je dle mého názoru dostačující, protože poměrně podrobně popisuje všechny části patentového řízení včetně návrhu i rozhodování o utajení. Avšak nejdůležitější část právních vztahů vyplývajících z udělení utajovaného patentu tedy ty mezi majitelem a státem, který nařídil utajení vynálezu - není popsána vůbec, lze říci, že pro majitele patentu nejsou žádné dostupné informace týkající se této otázky. Považovala bych v tomto ohledu za vhodné konkrétnější právní úpravu zahrnout do patentového zákona - vzorem by mohla úprava německého patentového zákona. Ten obsahuje základní obecné principy nakládání s utajovanými patenty a možnost požadovat fi- 
nanční kompenzaci včetně rámcově uvedeného způsobu jejího výpočtu. Taková úprava by byla transparentnější a srozumitelnější. Větší transparentnosti by dle mého názoru také přispělo pravidelné zveřejňování statistik týkajících se utajování patentů tak, jak jsou zveřejňovány statistiky všech udělených patenti̊ ve výročních zprávách Úřadu průmyslového vlastnictví.

Vzhledem k aktuální právní úpravě by však byla vhodná jakákoliv změna právní úpravy směrem v souladu s výše uvedeným.

\section{SEZNAM ZDROJŮ}

\subsection{MONOGRAFIE}

[1] FITZNER, Uwe et al. Beck'scher Online-Kommentar Patentrecht. 4. ed. München: C. H. Beck, 2017, 2221 s. ISBN 978-3-8006-3591-7.

[2] HORÁČEK, Roman a kol. Práva k průmyslovému vlastnictví. 3. dopl. a přeprac. vyd. Praha: C.H. Beck, 2017, 381 s. ISBN 978-80-7400-655-5.

[3] CHLOUPEK, Vojtěch a kol. Patentový zákon. Komentár̆. 1. vydání. Praha: C. H. Beck, 2017, 334 s. ISBN 978-80-7400-268-7.

[4] JAKL, Ladislav. Právní ochrana vynálezů a užitných vzorů: vypracování jejich popisů a nároků na ochranu. 1. vyd. Praha: Metropolitní univerzita Praha, 2010. 279 s. ISBN 978-80-86855-561.

[5] KNAP, Karel a kol. Práva k nehmotným statkưm. 1. vyd. Praha: Codex, 1994, 245 s. ISBN 80-901185-3-4.

[6] POSPÍŠIL, Michal a kol. Práva z průmyslového vlastnictví. 1. vyd. Praha: Vysoká škola aplikovaného práva, 2007, 231 s. ISBN 978-80-86775-17-3.

[7] SAMUEL, Geoffrey. An Introduction to Comparative Law Theory and Method. Oxford: Hart Publishing, 2014, 210 s. European Academy of Legal Theory series. ISBN 978-1-84946-643-1.

[8] ŠPIRK, Ludvík; VANĚK, Cyril. Výklad právních předpisů československého práva patentního: výklad zákona ze dne 11. ledna 1897, č. 30 ř. z., novelisovaného zákony ze dne 29. prosince 1908, č. 286 ř. z., ze dne 27. května 1919, č. 305 Sb. z. a n., ze dne 30. června 1922, č. 252 Sb. z. a n. a př́slušných nařízení. V Praze: Nákladem vlastním, 1933, 170 s.

[9] TAKENAKA, Toshiko. Patent law and theory: a handbook of contemporary research. Cheltenham, UK: Edward Elgar, 2008. Research handbooks in intellectual property. $790 \mathrm{~s}$. ISBN 978-1-84542-413-8.

[10] ÖRÜCÜ, A. Esin. Methodology of comparative law. In: SMITS, Jan M. Elgar Encyklopedia of Comparative Law. 1 ed. Cheltenham: Edward Elgar Publishing Limited, 2006, 840 s. ISBN-13: 9781845420130. 


\section{2 ČLÁNKY}

[11] CITRIN, Adam J. Are the Secrecy Order Compensation Provisions of the Patent Act Constitutional Under the Fifth Amendment? Akron Intellectual Property Journal [online], 2007, vol. 1, 25 s [cit. 25. 2. 2018]. Dostupné z: http://ideaexchange.uakron.edu/cgi/viewcontent.cgi? article $=1007 \&$ context $=$ akronintellectualproperty 22 .

[12] MACHLUP, Fritz; PENROSE, Edith. The Patent Controversy in the Nineteenth Century. The Journal of Economic History [online]. 1950, vol. 10, no. 1, s. 1 - 29 [cit. 6. 1. 2018]. ISSN 0022-0507.

[13] MAZZOLENI, Roberto; NELSON, Richard. The benefits and costs of strong patent protection: a contribution to the current debate. Research Policy [online]. 1998, vol. 27, no. 3, s. 273 - 284 [cit. 4. 1. 2018]. ISSN 0048-7333. Dostupné z: doi:10.1016/S0048-7333(98)000481

[14] RUTTAN, Vernon W. Is War Necessary for Economic Growth?: Military Procurement and Technology Development. B.m.: Oxford University Press, 2006. 232 s. [cit. 25. 2. 2018]. ISBN 978-0-19-804065-1.

\subsection{JUDIKATURA}

[15] Nález Ústavního soudu ze dne 16. června 2011 sp. zn. II. ÚS 1392/11. In: Beck-online [online právní informační systém]. Nakladatelství C. H. Beck [cit. 25. 2. 2018]. Dostupné z: https://www.beck-online.cz/bo/documentview.seam?documentId = njptembrgfpxk427ge3tkni

[16] Odlišné stanovisko Pavla Höllandera k nálezu pléna Ústavního soudu ze dne 3. 4. 1996, sp. zn. Pl. ÚS 32/95. In: Beck-online [online právní informační systém]. Nakladatelství C. H. Beck [cit. 25. 2. 2018]. Dostupné z: https://www.beck-online.cz/bo/document-view.seam?documentId $=$ njptcojzgzptens7ovzw4

[17] SPOJENÉ STÁTY. Rozsudek Okresního soudu v Massachusetts ve věci Stein v. United States ze dne 6. dubna 2001, sp. zn. [135 F. Supp. 2d 265]

\subsection{INTERNETOVÉ ZDROJE}

[18] ARMED SERVICES PATENT ADVISORY BOARD. Patent Security Category Review List [online]. Federation of American Scientists, (C) 2018 [cit. 15. 3. 2018]. Dostupné z: https://fas.org/sgp/othergov/invention/pscrl.pdf

[19] Guidance. National security checks on patent applications - GOV.UK [online]. (C) Crown Copyright, publikováno 9. 4. 2014 [cit. 15. 3. 2018]. Dostupné z: https://www.gov.uk/guidance/national-security-checks-on-patent-applications

[20] Národní patenty a validované evropské patenty platné na území České republiky k 31. 12. 2017, Výroční zpráva Úřadu průmyslového vlastnictví České republiky 2017. [online]. Úřad průmyslového vlastnictví, 2018, [cit. 20. 6. 2018]. Dostupné z: https://www.upv.cz/cs/publikace/rocenka/rocenka.html. 
[21] NATO uklidňuje Trumpa, výdaje rostou. Česko je čtvrté od konce. iDnes.cz [online]. () MAFRA 1999 - 2018, publikováno 13. března 2017 [cit. 25. 2. 2018]. Dostupné z: https://zpravy.idnes.cz/vydaje-nato-na-obranu-rostoudgx-/zpr_nato.aspx?

c $=$ A170313_191335_zpr_nato_inc

[22] Official Statistics. Facts and figures: patent, trade mark, design and hearing data: 2016 GOV.UK [online]. (C) Crown Copyright, publikováno 2. 11. 2017 [cit. 15. 3. 2018]. Dostupné z: https://www.gov.uk/government/statistics/facts-and-figures-patent-trade-mark-design-andhearing-data-2016

[23] Resortní rozpočet. Ministerstvo obrany České republiky [online]. Copyright (C) Ministerstvo obrany, publikováno 26. června 2017 [cit. 25. 2. 2018]. Dostupné z: http://www.mocr.army.cz/finance-a-zakazky/resortni-rozpocet/resortni-rozpocet-5146/

[24] TABLE 1: Summary of Patent Examining Activities (FY 2013 - FY 2017). United States Patent and Trademark Office: Performance and Accountability Report FY 17 [online]. United States Patent and Trademark Office, 2017, s. 172 [cit. 15. 3. 2018]. Dostupné z: https://www.uspto.gov/sites/default/files/documents/USPTOFY17PAR.pdf

[25] Technology which may be subject to section 22 of The Patents Act. Technology prejudicial to national security or public safety - GOV.UK [online]. (C) Crown Copyright, publikováno 25. 2. 2008 [cit. 15. 3. 2018]. Dostupné z: https://www.gov.uk/government/uploads/system/uploads/attachment_data/file/307009/p-securitylist.pdf

[26] The Secrecy Order Program in the United States Patent \& Trademark Office. Federation of American Scientists, (c) 2018 [cit. 15. 3. 2018]. Dostupné z: https://fas.org/sgp/othergov/invention/program.html

[27] Total Secrecy Orders in effect (at end of period). Invention Secrecy Activity (as reported by The Patent and Trademark Office) [online]. Federation of American Scientists, (c) 2018 [cit. 15. 3. 2018]. Dostupné z: https://fas.org/sgp/othergov/invention/stats.html

[28] Vyhledávání ve Věstníku podle bibliografických údajů [online]. Úřad průmyslového vlastnictví, 2018, [cit. 5. 7. 2018]. Dostupné z: https://isdv.upv.cz/webapp/webapp.vestnik.lst_pt.

\subsection{PRÁVNÍ PŘEDPISY}

[29] Nařízení vlády č. 240/2008 Sb., kterým se mění nařízení vlády č. 522/2005 Sb., kterým se stanoví seznam utajovaných informací, ve znění pozdějších 86 předpisů. In: Beck-online [online právní informační systém]. Nakladatelství C. H. Beck [cit. 25. 2. 2018]. Dostupné z: https://www.beck-online.cz/bo/chapterview-document.seam?documentId = onrf6mrqga4f6mrugawta

[30] Nařízení vlády č. 522/2005 Sb., kterým se stanoví seznam utajovaných informací, ve znění pozdějších předpisů. In: Beck-online [online právní informační systém]. Nakladatelství C. H. Beck [cit. 25. 2. 2018]. Dostupné z: https://www.beck-online.cz/bo/chapterview-document.seam?documentId $=$ onrf6mrqga2v6njsgiwte 
[31] NĚMECKO. § 50 - § 56 Patengesets vom 16. Dezember 1980, BGBl. 1981 I S. 1 [cit. 25. 2. 2018]. Dostupné z: http://www.gesetze-im-internet.de/patg/

[32] NĚMECKO. Strafgesetzbuch vom 13. November 1998, BGBl. I S. 3322 [cit. 25. 2. 2018]. Dostupné z: https://www.gesetze-im-internet.de/stgb/

[33] SPOJENÉ KRÁLOVSTVÍ. Sec. 22 - 23. Patents Act of 1977, Chapter 37 [cit. 25. 2. 2018]. Dostupné z: https://www.legislation.gov.uk/ukpga/1977/37

[34] SPOJENÉ STÁTY. § 181 et seq. Invention Secrecy Act of 1951, Title 35 of United States Code, Pub. L. 82-256 [cit. 25. 2. 2018]. Dostupné z: http://www.wipo.int/wipolex/en/details.jsp?id $=5399$

[35] Usnesení České národní rady č. 2/1993 Sb., o vyhlášení Listiny základních práv a svobod, ve znění pozdějších předpisů. In: Beck-online [online právní informační systém]. Nakladatelství C. H. Beck [cit. 25. 2. 2018]. Dostupné z: https://www.beck-online.cz/bo/chapterviewdocument.seam?documentId $=$ onrf6mjzhezv6mrnge

[36] Vyhláška č. 275/2015 Sb., kterou se mění vyhláška č. 529/2005 Sb., o administrativní bezpečnosti a o registrech utajovaných informací, ve znění pozdě- jších předpisů. In: Beck-online [online právní informační systém]. Nakladatelství C. H. Beck [cit. 25. 2. 2018]. Dostupné z: https://www.beck-online.cz/bo/chapterview-document.seam?documentId = onrf6mrqge2v6mrxguwta

[37] Vyhláška č. 529/2005 Sb., o administrativní bezbepečnosti a o registrech utajovaných informací. In: Beck-online [online právní informační systém]. Nakladatelství C. H. Beck [cit. 25. 2. 2018]. Dostupné z: https://www.beckonline.cz/bo/chapterview-document.seam?documentId $=$ onrf6mrqga2v6njshewtg

[38] Vyhláška Federálního úřadu pro vynálezy č. 550/1990 Sb., o řízení ve věcech vynálezůa a průmyslových vzorů. In: Beck-online [online právní informační systém]. Nakladatelství C. H. Beck [cit. 25. 2. 2018]. Dostupné z: https://www.beck-online.cz/bo/chapterview-document.seam?documentId = onrf6mjzheyf6njvgawtc

[39] Zákon č. 150/2002 Sb., soudní řád správní, ve znění pozdějších předpisů. In: Beck-online [online právní informační systém]. Nakladatelství C. H. Beck [cit. 25. 2. 2018]. Dostupné z: https://www.beck-online.cz/bo/chapterview-document.seam?documentId = onrf6mrqgazf6mjvgawtgmq

[40] Zákon č. 183/2017 Sb., kterým se mění některé zákony v souvislosti s přijetím zákona o odpovědnosti za přestupky a řízení o nich a zákona o některých přestupcích, ve znění pozdějších předpisů. In: Beck-online [online právní informační systém]. Nakladatelství C. H. Beck [cit. 25. 2. 2018]. Dostupné z: https://www.beck-online.cz/bo/chapterview-document.seam? documentId $=$ onrf6mrqge3v6mjygmwtg

[41] Zákon č. 305/1919 Sb., jenž se týká prozatímních opatření na ochranu vyná- lezů, ve znění pozdějších předpisů. In: Beck-online [online právní informační systém]. Nakladatelství C. H. Beck [cit. 25. 2. 2018]. Dostupné z: 90 https://www.beck-online.cz/bo/chapterview-document.seam?documentId = onrf6mjzge4v6mzqguwta 
[42] Zákon č. 412/2005 Sb., o ochraně utajovaných informací a bezpečnostní způsobilosti. In: Beck-online [online právní informační systém]. Nakladatelství C. H. Beck [cit. 25. 2. 2018]. Dostupné z: https://www.beck-online.cz/bo/chapterview-document.seam? documentId $=$ onrf6mrqga2v6nbrgiwtema

[43] Zákon č. 500/2004 Sb., správní řád, ve znění pozdějších předpisů. In: Beck-online [online právní informační systém]. Nakladatelství C. H. Beck [cit. 25. 2. 2018]. Dostupné z: https://www.beck-online.cz/bo/chapterview-document.seam?documentId = onrf6mrqga2f6njqgawtcmq

[44] Zákon č. 527/1990 Sb., o vynálezech, průmyslových vzorech a zlepšovacích návrzích. . In: Beck-online [online právní informační systém]. Nakladatelství C. H. Beck [cit. 25. 2. 2018]. Dostupné z: https://www.beck-online.cz/bo/chapterview-document.seam? documentId = onrf6mjzheyf6njsg $4 \mathrm{wtcmi}$

[45] Sdělení Ministerstva zahraničních věcí č. 69/2002 Sb. m. s., o př́stupu České republiky k Úmluvě o udělování evropských patentů (Evropské patentové úmluvě), ve znění pozdějších změn. In: Beck-online [online právní informační systém]. Nakladatelství C. H. Beck [cit. 25. 2. 2018]. Dostupné z: https://www.beck-online.cz/bo/chapterview-document.seam? documentId = onrg2427giydams7gy4s2my

[46] Sdělení Ministerstva zahraničích věcí č. 17/2003 Sb. m. s., o sjednání Dohody o vzájemném zabezpečení utajení vynálezů týkajících se obrany, na něž byla podána žádost o udělení patentu, ve znění pozdějších změn. In: Beck-online [online právní informační systém]. Nakladatelství C. H. Beck [cit. 25. 2. 2018]. Dostupné z: https://www.beck-online.cz/bo/documentview.seam?documentId $=$ onrg2427giydam27ge3s2ma\&tocid $=$ onrg2427giydam27ge3s2ma

[47] Agreement for the mutual safeguarding of secrecy of inventions relating to defence and for which applications for patents have been made. United Nations Treaty Collection [online]. (C) UNITED NATIONS [cit. 28. 2. 2018]. Dostupné z: https://treaties.un.org/Pages/showDetails.aspx?objid $=08000002801376 \mathrm{e} 0$

[48] Sdělení federálního ministerstva zahraničních věcí č. 296/1991 Sb., o uložení listiny o přístupu České a Slovenské Federativní Republiky ke Smlouvě o patentové spolupráci, sjednané ve Washingtonu dne 17. června 1970, ve znění pozdějších změn. In: Beck-online [online právní informační systém]. Nakladatelství C. H. Beck [cit. 25. 2. 2018]. Dostupné z: https://www.beck-online.cz/bo/chapterview-document.seam?

documentId $=$ onrf6mjzheyv6mrzgywtena

\subsection{OSTATNÍ}

[49] Instrukce předsedy Úřadu průmyslového vlastnictví, kterou se stanoví standard úpravy přihlášky vynálezu, žádosti o udělení dodatkového ochranného osvědčení a přihlášky užitného vzoru. Úřad průmyslového vlastnictví [online]. Copyright 2008 Úřad průmyslového vlastnictví [cit. 25. 2. 2018]. Dostupné z: https://www.upv.cz/cs/prumyslova-prava/vynalezypatenty/Instrukcepredsedy-UPV.html

[50] THE CHARLES STARK DRAPER LABORATORY, INC. Fused PM fiber singlepolarisation resonator. United States of America. US 9115993 B1. 30. 8. 1990. 
[51] Důvodová zpráva k zákonu č. 412/2005 Sb., o ochraně utajovaných informací a o bezpečnostní způsobilosti. In: Beck-online [online právní informační systém]. Nakladatelství C. H. Beck [cit. 25. 2. 2018]. Dostupné z: https://www.beck-online.cz/bo/document-view.seam?documen- 94 tId $=$ oz5f6mrqga2v6nbrgjpwi6q\&groupIndex $=0$ \&rowIndex $=0$ \&relationType $=$ reference\&referenceType $=$ active\&referenceName $=$ dz\&originalDocumentId $=$ onrf6mrqga2v6nbrgiwtema\&showLowerSectionsRelations $=$ false\&activeFacets $=11 \&$ sortType $=$ sorted rank-rp\&firstPage $=0$ \& currentPage $=0$

[52] Bezpečnostní rád Úřadu průmyslového vlastnictví.

[53] Metodický pokyn pro řízení před Úřadem průmyslového vlastnictví: Část B.

[54] Důvodová zpráva k zákonu č. 183/2017 Sb. In: Beck-online [online právní informační systém]. Nakladatelství C. H. Beck [cit. 25. 2. 2018]. Dostupné z: https://www.beckonline.cz/bo/document-relations.seam?relationType $=$ reference\&referenceType $=$ active\&referenceName $=\mathrm{dz} \&$ documentId $=$ onrf6mrqge $3 \mathrm{v} 6$ mjygmwtg\&showLowerSectionsRelations $=$ false

[55] WIPO standard st. 17: Recommendation for the coding of headings of announcements made in official gazettes. Handbook on industrial property information and documentation [online]. World intellectual property organization [cit. 28. 2. 2018]. Dostupné z: http://www.wipo.int/standards/en/part_03_standards.html

[56] WIPO standard st. 9: Recommendation concerning bibliographic data on and relating to patents and SPCS. Handbook on industrial property information and documentation [online]. World intellectual property organization [cit. 28. 2. 2018]. Dostupné z: http://www.wipo.int/standards/en/part_03_standards.html

[57] SELLIER AND BELLOT A. S. VLAŠIM. Roznětka pro zapalovače. Původce: Václav SVACHOUČEK. Česká republika. Patentový spis CZ 299391 B6. 30. 1. 1997.

[58] SELLIER AND BELLOT A. S. VLAŠIM. Zážehová směs. Původce: Jiří NESVEDA, Stanislav BRANDEJS, Radek KOTOUČEK. Česká republika Patentový spis CZ 299392 B6. 13. 8. 1996.

[59] SELLIOR AND BELLOT A. S. VLAŠIM. Iniciační slož pro trasovací slož. Pů- vodce: Václav SVACHOUČEK. Patentový spis CZ 299393 B6. 21. 12. 1998. 13.

[60] MINISTERSTVO OBRANY ČR, ODBOR VĚCNÝCH ZDROJŮ A SPRÁVY ORGANIZACÍ PRAHA. Hydraulická zákluzová brzda s ventilem. Původce: Milan VAŠÍ- ČEK, Josef MANĎÁK. Autorské osvědčení CZ 299396 B1. 22. 4. 1986. 14.

[61] ZVI A. S. PRAHA. Zážehová slož pro elektricky iniciovatelné zápalky. Původci: Václav SVACHOUČEK, Jan KUSÁK, Jiří STRNAD. Česká Republika. Patentový spis CZ 295050 B6. 11. 3. 2005.

Toto dílo lze užít v souladu s licenčními podmínkami Creative Commons BY-SA 4.0 International (http://creativecommons.org/licenses/by-sa/4.0/legalcode). 